\title{
PROTOTIPE PERMAINAN EDUKATIF 3D PUZZLE RUMAH GADANG RAJO BABANDIANG
}

\author{
Fariko Edwardi ${ }^{1}$ \\ Program Studi Desain Komunikasi Visual, Universitas Indraprasta PGRI \\ Correspondence author: Fariko Edwardi, farikoedwardi@gmail.com, Bekasi, and Indonesia
}

\begin{abstract}
Abstrak. 3D puzzle merupakan kategori permainan teka-teki mengasah pikiran berbentuk bongkar pasang, yang mengunakan elemen-elemen menjadi struktur bangunan tiga dimensi. Cukup banyak $3 D$ puzzle yang menjadikan sebagai media pembelajaran bagi penggunanya, akan tetapi sangat sedikit permainan $3 D$ puzzle ini muncul dipasaran tentang bangunan rumah adat, apalagi yang memiliki tingkat intelegensi untuk menyusun elemen puzzle yang dapat menyampaikan keterangan struktur, fungsi dan makna. Sesuatu permasalahan yang terjadi pada masyarakat modern Minangkabau saat ini, terhadap perubahan bentuk dan tidak sesuai lagi dari fungsi, dan makna sebenarnya, akan berakibat citra arsitektur dari rumah adat (Rumah Gadang) Minangkabau yang muncul seolah sudah cukup terwakili oleh satu atau beberapa elemen dari Rumah Gadang, seperti atap gonjongnya saja. Kekhawatiran ini dapat secara tidak langsung masyarakat Minangkabau mulai mengubur jati diri arsitekturalnya. Metode analisis perancangan berbasis riset dengan menggunakan data primer berupa temuan fenomena yang terjadi saat ini, dan sekunder sebagai data tambahan untuk memperkuat data primer seperti sumber kajian tertulis dan sumber karya sebagai referensi permainan edukatif. Oleh karena itu, Rumah Gadang sebagai sumber ide penciptaan untuk merancang berupa prototipe 3D puzzle bertujuan memberikan pengetahuan dan edukasi tentang nilai dan makna yang terdapat pada Rumah Gadang sebagai lambang kebesaran suku masyarakat Minangkabau.
\end{abstract}

Keywords: Minangkabau, 3D puzzle, permainan edukatif, revitalisasi

\begin{abstract}
D puzzle is a category of logic games in the form of unloading pairs, which uses elements into three-dimensional building structures. Quite a lot of $3 d$ puzzles make as a learning media for users, but very few of these 3D puzzle games appear on the market about traditional house buildings, especially those that have a level of intelligence to compose puzzle elements that can convey descriptions of structure, function and meaning. Something of a problem that occurs in modern Minangkabau society today, against the change of form and no longer fit of function, and its true meaning, will result in the architectural image of the Minangkabau traditional house (Rumah Gadang) that appears as if it is adequately represented by one or several elements of the Rumah Gadang, such as the roof of the gonjong only. This concern could indirectly the Minangkabau people begin to bury their architectural identity. Research-based design analysis method using primary data in the form of findings of current phenomena, and secondary as additional data to strengthen primary data such as written study sources and work sources as educational game references. Therefore, Rumah Gadang as a source of creation ideas to design a prototype 3D puzzle aims to provide knowledge and education about the value and meaning contained in the Rumah Gadang as a symbol of the greatness of the Minangkabau people.
\end{abstract}

Keywords: Minangkabau, 3D puzzle, educational game, revitalizing 


\section{Pendahuluan}

Berbicara tentang Sumatera Barat, terlintas Minangkabau menjadi suku asal dari daerah tersebut. Ragam budaya Minangkabau telah menjadi aset yang sangat bernilai dalam masyarakat Sumatera Barat, baik itu berupa adat istiadat, agama, kesenian tradisi, masakan, dan tidak kalah pentingnya rumah adat yang dimiliki oleh suku Minangkabau, yang disebut juga dengan Rumah Gadang. Rumah Gadang merupakan salah satu bentuk warisan budaya Indonesia yang patut dilestarikan sampai kapanpun perkembangannya.

Penamaan Rumah Gadang bukan berarti rumah yang besar saja, tetapi juga memiliki fungsi dan keunikan pada setiap bagian rumahnya. Penjelasan dalam Kamus Besar Bahasa Indonesia, Rumah Gadang yang berarti rumah induk tempat tinggal kaum keluarga. Ensiklopedi juga menjelaskan bahwa Rumah Gadang merupakan rumah tradisional yang menjadi ciri keluarga besar matrilineal di daerah Minangkabau. Selain fungsi sebagai tempat tinggal keluarga, Rumah Gadang juga menjadi sumber pengaturan segala sesuatu yang menyangkut kehidupan para kerabat matrilineal dan merupakan identitas lokal dari suku Minangkabau sebagai warisan pusaka dari nenek moyang terdahulu.

Matrilineal merupakan panutan masyarakat Minangkabau yang bersuku ke ranji ibu. karena dalam sistem kekerabatan Minangkabau sosok perempuan merupakan lambang keturunan suku, sebagaimana anak yang bersuku ke ibu, baik itu anak laki-laki maupun anak perempuan. Rumah Gadang diwariskan ke kaum ibu disebut limpapeh, ditempati bersama suami serta anak perempuan, dan suami anaknya. Landasan kekeluargaan dimulai dari rumah tangga, ibu yang diberi nama limpapeh rumah nan gadang adalah lambang keturunan (Hasan 2004, 119).

Sebagaimana penjelasan tentang pembangunan Rumah Gadang oleh Navis (1984), di antaranya perlu diperhatikan lokasi mendirikan dan jumlah gonjongnya, mendirikan rumah (batagak rumah) di atas tanah kaum bekerja sama secara bergotong-royong dan dibantu oleh kaum yang lain. Ketentuan adat menetapkan bahwa Rumah Gadang yang bergonjong lebih dari empat hanya boleh didirikan pada perkampungan yang berstatus Nagari atau Koto. Pada perkampungan kecil hanya boleh didirikan Rumah Gadang yang bergonjong dua, sedangkan di Taratak tidak boleh mendirikan Rumah Gadang yang bergonjong, dalam membangun Rumah Gadang tidak bisa menurut kehendak sendiri, karena sifatnya yang bergotong-royong dan bermufakat sesama kaum, baik penempatan lokasi, pengumpulan bahan, maupun menentukan hari pelaksanaan pembangunan, sehingga pembangunan Rumah Gadang tidak menyalahi aturan yang berlaku dan tidak menimbulkan permasalahan dikemudian hari.

Bentuk fisik atau dari segi visual Rumah Gadang berbeda dari rumah adat lainnya, jika dilihat dari keseluruhan, pada bagian badan rumah menyerupai bentuk perahu, yang besar ke atas dengan dinding bagian atas miring ke arah luar dan pada perahu juga terdapat buritan yang diimplentasikan pada anjuang. Bagian atap berupa gonjong yang menyerupai lengkungan bentuk tanduk kerbau. Bentuk gonjong juga merupakan pengambaran bentuk susunan daun sirih yang selalu disuguhkan pada upacara adat dan bermakna sakral, sementara tonggaknya berbentuk delapan persegi dan dindingnya dibentuk dengan ragam hias motif ukiran Minangkabau.

Setelah mengetahui sejarah dari warisan budaya lampau, perubahan budaya yang disebabkan oleh perkembangan zaman yang serba instan, canggih oleh sentuhan teknologi yang mutakhir, kondisi Rumah Gadang tidak lagi seperti dahulu kala, baik keberadaannya maupun fungsinya. Menurut penjelasan Putiah (2007) dahulu rumah kaum banyak ditempati oleh keluarga keturunan ibu, kini dirumah tersebut di berbagai daerah banyak yang kosong, lapuk dan runtuh. Perubahan tersebut diakibatkan oleh persoalan yang ada dalam kaum maupun pengaruh yang datang dari luar, di antaranya muncul dari persoalan ekonomi keluarga yang 
semakin sulit, sehingga sebagian keluarga memilih untuk merantau guna memenuhi tuntutan ekonomi, sebaliknya bagi keluarga yang merasa ekonominya sudah mapan, sehingga muncul keinginan untuk membangun rumah sendiri, sehingga lama kelamaan Rumah Gadang ditinggalkan oleh kaumnya.

Pada zaman sekarang Rumah Gadang dapat dibangun siapapun dan dimanapun baik untuk pribadi maupun pemerintahan. Bahan bangunannya telah dibuat dari beton, bukan lagi kayu, hanya bagian gonjongnya saja yang masih menyisakan bentuk yang tidak berubah dari Rumah Gadang sesungguhnya.

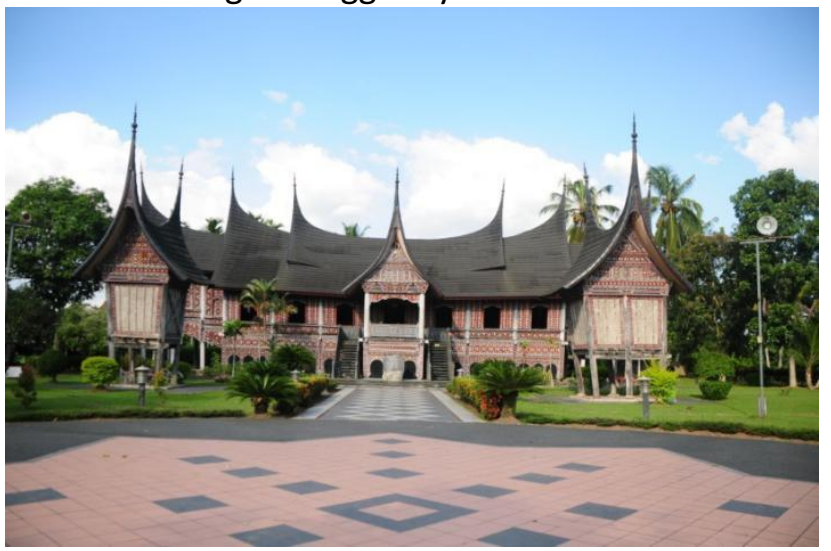

Gambar 1 Rumah Gadang Rajo Babandiang. Sungai Beringin, Payakumbuh (Fariko, 2017)

Berbagai fakta dan masalah yang ditemukan, gejala peniruan arsitektur Rumah Gadang yang menerapkan bentuk aksen gonjong yang sering ditemui pada bangunan modern, seperti halnya pada bangunan perkantoran, pertokoan, atap lahan parkiran, bahkan kandang burung juga memiliki aksen gonjong, sehingga kesan pencitraan penerapannya dapat melanggar nilai etika di Minangkabau, yang dapat merubah persepsi masyarakat terhadap Rumah Gadang tersebut. Kalau peniruan ini bertujuan memelihara kelestarian budaya asli, maka peniruan tersebut dapat dijelaskan dan diperlihatkan, sesuai dengan maksud tujuannya. Supaya masyarakat atau generasi yang akan datang dapat mempelajari tentang kearifan lokal yang berguna untuk keberlangsungan hidup bermasyarakat, yang beradat dan bermartabat. Sesuai dengan falsafah adat di Minangkabau, "adat basandi syarak, syarak basandi kitabullah" Adat bersendikan pada agama dan agama bersendikan pada kitab Allah yaitu Al-Qur'an. Artinya, segala tata aturan adat untuk mengatur kehidupan masyarakat, dibuat berdasarkan kitabullah (Rasmida 2015).

Berdasarkan uraian di atas, agar Rumah Gadang dikemudian hari tidak menjadi kenangan semata, maka sebagai sumber ide dalam penciptaan karya desain komunikasi visual ini adalah bentuk fisik Rumah Gadang yang akan diterapkan dalam media permainan (game) edukasi yang berupa bentuk permainan teka-teki bongkar pasang (puzzle). Pada permainan edukasi ini nantinya dirancang menjadi sarana untuk pengetahuan, pendidikan dan membangkitkan intelegensi bagi penggunanya.

Berbagai permasalahan yang telah disimpulkan, maka penciptaan karya DKV nantinya difokuskan menjadi karya yang komunikatif untuk target audience berupa prototipe puzzle 3 Dimensi, dimana puzzle ini berbentuk fisik dari Rumah Gadang yang memiliki bagian anjung kiri dan kanan, serta memiliki gonjong enam disebut juga Rajo Babandiang, dan tidak menutup kemungkinan project desain ini akan dikembangkan menjadi diorama perkampungan Minangkabau nantinya. Dimana diorama menurut penjelasan pada adalah sejenis benda miniatur tiga dimensi untuk menggambarkan suatu pemandangan atau suatu adegan. Asal usul diorama adalah dekorasi teater di Eropa dan Amerika pada abad ke-19. Amalia, Agustina, and Sulianto (2017) menjelaskan Diorama adalah sebuah pemandangan tiga dimensi mini bertujuan 
untuk menggambarkan pemandangan sebenarnya. Diorama biasanya terdiri atas bentuk-bentuk sosok atau objek-objek ditempatkan di pentas yang ber-latar belakang lukisan yang disesuiakan dengan penyajian.

Penciptaan permainan edukasi berupa 3D puzzle Rumah Gadang Rajo Babandiang ini, tidak hanya permainan bongkar pasang saja, dimana setiap elemen-elemen atau bagian puzzle ini memiliki penomoran atau kode tertentu, untuk berfungsi sebagai keterangan makna dalam bagian pada bangunan Rumah Gadang tersebut. Rancangan dalam penciptaan karya DKV ini berangkat dari rasa keprihatinan terhadap keberadaan Rumah Gadang di zaman modern yang sudah mulai dilupakan oleh masyarakat pendukungnya, dengan tujuan agar mengingatkan kembali masyarakat bahwa Rumah Gadang sebagai hasil budaya masa lampau, bernilai sejarah, pendidikan, dan bernilai estetis yang patut dilestarikan agar warisan budaya Minangkabau tidak luntur oleh perkembangan zaman, dan selalu hadir di masa sekarang dan masa yang akan datang.

Untuk mewujudkan gagasan kreatif tersebut, banyak pertimbangan dan analisis yang harus dilakukan terahadap sumber ide, analisis pemilihan bahan, pembentukan, finishing dan penyajian karya. percobaan-percobaan terhadap kemungkinan serta pencarian bentuk yang dapat mewakili gagasan, maupun yang dapat disampaikan melalui karya selalu dilakukan.

\section{Metode}

Metode yang digunakan dalam perancangan prototype 3D puzzle Rumah Gadang ini adalah metode kualitatif, yakni metode perancangan berbasis riset dengan bagian data primer dan data sekunder, data primer merupakan hasil pengamatan dilapangan. Data Sekunder sebagai data tambahan yang merupakan keterangan dan informasi, dari sumber kajian tertulis, terutama dari media game edukatif dan rumah adat tradisi Minangkabau. Data sekunder ini dari disertasi, buku, internet wawancara, dan observasi, data sekunder digunakan untuk memperkuat data primer. Moleong (2019) mengungkapkan bahwa data-data tersebut dikumpulkan dari naskah wawancara, catatan lapangan, foto, video dan dokumen pribadi serta dokumen resmi lainnya yang berhubungan dengan penelitian. Merancang karya 3D puzzle Rumah Gadang memerlukan strategi analisis data dengan persiapan studi visual, pengamatan, observasi, wawancara, dokumentasi, studi pustaka, eksperimen.

Perancangan prototype 3D puzzle Rumah Gadang ini mengunakan metode analisis $5 \mathrm{~W}+1 \mathrm{H}$, hal ini dikarenakan pentingnya metode analisis ini untuk menjawab pemecahan masalah dalam proses perancangan 3D puzzle. Yin (2013) menjelaskan penggunaan metode $5 \mathrm{~W}+1 \mathrm{H}$ adalah untuk menentukan jawaban yang telah diketahui mengenai suatu topik, agar peneliti dapat mengembangkan pertanyaan-pertanyaan yang lebih tajam dan bermakna. What apa yang akan dibuat? Rancangan yang akan dibuat yaitu perancangan 3D puzzle Rumah Gadang memanfaatkan arsitektur Rumah Adat Minangkabau sebagai sumber ide gagasan. Where, dimana diaplikasikan/diterapkan? diaplikasikan di daerah Sumatera Barat. When, kapan dimulai? masa sekarang dan selanjutnya. Who, siapa target sasaran? pelajar 9 tahun ke atas, berbagai kalangan. Why, mengapa rancangan 3D puzzle Rumah Gadang perlu dibuat? Untuk menciptakan Rumah Adat Minangkabau melalui media permainan puzzle, yang berguna untuk menarik perhatian dan pengetahuan tentang struktur dan makna dari Rumah Gadang. How, bagaimana merancang 3D puzzle Rumah Gadang tersebut? puzzle yang dirancang harus mampu mengangkat citra Rumah Gadang sebagai identitas budaya lokal Minangkabau, dengan memanfaatkan falsafah, struktur, fungsi dan makna Rumah Gadang yang akan dirancang menjadi puzzle. 
Kajian Konsep setelah menganalisis data dilakukan, data-data yang didapat dari hasil analisis digunakan untuk merangkum konsep perancangan. Hasil dari analisis data digambarkan pada proses brainstorming untuk mendapatkan konsep perancangan yang lebih jelas. Konsep perancangan digunakan dalam perancangan 3D puzzle Rumah Gadang. Konsep terdiri dari 2 (dua), yaitu konsep visual dan konsep verbal. Konsep ini akan digunakan pada tahapan perancangan mulai dari pemilihan pola bangunan Rumah Gadang, dan teknis dalam memasang simbol pada elemen puzzle yang berfungsi sebagai penjelasan pada bagian-bagian penting dari puzzle Rumah Gadang. Setelah melakukan kajian konsep perancangan tahapan selanjutnya adalah visualisasi perancangan terdiri dari sketsa desain, gambar kerja, alternatif bahan untuk pembuatan prototype, dan desain komperhensif. Tahapan ini merupakan akhir dari perancangan yang menghasilkan rancangan final.

\section{Hasil dan Pembahasan}

\section{Kajian Teori}

Budaya visual Minangkabau seperti bentuk gonjong bangunan, bukanlah hasil budaya visual yang dibentuk kemudian setelah Islam masuk ke Minangkabau. Tetapi produk budaya era Hindu dan Budha. Sebagai contoh, aturan gonjong mesti empat, pembagian ruang yang empat buah pada Rumah Gadang, atau tonggak nan salapan, adalah sisa dari budaya lama yang menggambarkan mitos lama seperti hasta brata (delapan sifat kepemimpinan atau dewa), yang pengurangan terjadi pada jaman Perpatih Nan Sabatang dan Dt. Ketamanggungan, yang awalnya delapan sifat kepemimpinan dan akhirnya direduksi menjadi empat sifat alam, selanjutnya alam takabang jadi guru dan segala sesuatu yang serba empat. Ada kata-kata kiasan yang mengatakan "Kalau indak tahu nan siampek inyo bukan urang minang" (kalau tidak tahu dengan serba empat, dia bukan orang minang). Maksudnya dalam bertutur kata dan berprilaku (Couto 2008, 57).

Bentuk bangungan, dinding, tiang, atap atau gonjong yang sebelumnya telah diramu oleh tukang tuo atau tukang ahli seperti yang dikemukakan oleh Syamsul Asri dalam disertasinya pada Couto (2008) menjelaskan pembangunan pada saat ini peran tukang baru menyesuaikan bentuk pola bangunan dengan kebiasaan setempat. Salah satu contohnya adalah dalam menginterpretasikan adanya aturan adat yang mengatur bangunan bercorak Koto Piliang memiliki anjuang, dan Bodi Chaniago yang tidak memiliki anjung adalah contoh interpretasi yang dibentuk kemudian dan mungkin keliru. Pandangan ini telah diteliti oleh Syamsul Asri membuktikan lebih kurang dari 300 Rumah Gadang yang diteliti, di Kabupaten Tanah Datar hanya ditemukan 5 yang bercorak bangunan beranjung dan 4 di antaranya adalah ada di Limo Kaum sebagai pusat adat kelarasan Bodi Chaniago, bukan kelarasan Koto Piliang. Kesalahan interpretasi ini dimulai dari hasil penelitian penelitian kerja lapangan. Sebuah aturan adat terbentuk bukan hanya dalam mitos atau ucapan, tetapi kebiasaan yang meneruskan secara faktual, dilihat juga bagaimana sebuah kelembagaan itu terbentuk oleh manusia, begitu juga adat dan disebut tradisi. Misalnya budaya non-visual seperti pidato adat, nyanyian, musik, dan sebagainya. Oleh karena itu budaya intangible Minangkabau lebih menonjol daripada budaya visualnya. Jika ingin mengetahui seni budaya Minangkabau sebenarnya bisa dipandang dari cara berfikirnya, sastranya, pidato adat dan nyanyiannya (Couto 2008, 59).

Jika digali dari makna budaya visual Minangkabau yang ada sekarang dalam perspektif yang asli. Maknanya justru bukan hasil pemikiran manusia Minang masa kini, tetapi hasil dari kerangka pemikiran budaya masa lalu, yang diduga membidani kelahiran budaya visual ini. Jadi bukan dari konsep pemikiran dan ekspresi seni yang tumbuh kemudian, misalnya konsep tigo 
tungku sajarangan, adalah produk selepas perang Padri akhir abad ke 19, atas konflik kaum adat dan agaman yang disebut dengan Perjanjian Marapalam.

\section{Psikologi persepsi rumah adat Minangkabau}

Istilah Rumah Gadang (besar) oleh Ibenzani dalam disertasinya 1985 menyebutkan sebagai "lambang kebesaran suku", secara psikologis sebenarnya adalah cerminan jiwa perempuan yang menginginkan rumahnya menonjol sebagai eksitensi suku dan keturunannya. Atau ingin menonjolkan kelebihan mereka dibanding dengan orang lain. Dapat dikatakan bahwa Rumah Gadang di ukir hanya tampak depan rumah saja, sedangkan bagian belakang rumah di buat anyaman dinding dari bambu.

Estetika sosial yang menjadi kajian psikologi persepsi terhadap bangunan Rumah Gadang adalah pantulan psikologis keinginan perempuan yang ingin kelihatan indah. Hal ini diungkapkan dengan ukiran bangunan yang hanya pada bagian depan bangunan.

Berikut data sumber kajian tertulis disertasi Ibenzani Ibenzani, yang membahas tentang rumah adat Minangkabau, yang mengurai fungsi utama dari Rumah Gadang adalah sebagai tempat pusat kesatuan sosial terkecil yang berhubungan dengan sistem yang terdapat pada tatanan sosialnya. Sehingga banyak sekali kegiatan ataupun aktifitasnya, seperti tempat kediaman, tempat mendidik anak-kemenakan, tempat perhelatan, musyawarah dalam keluarga.

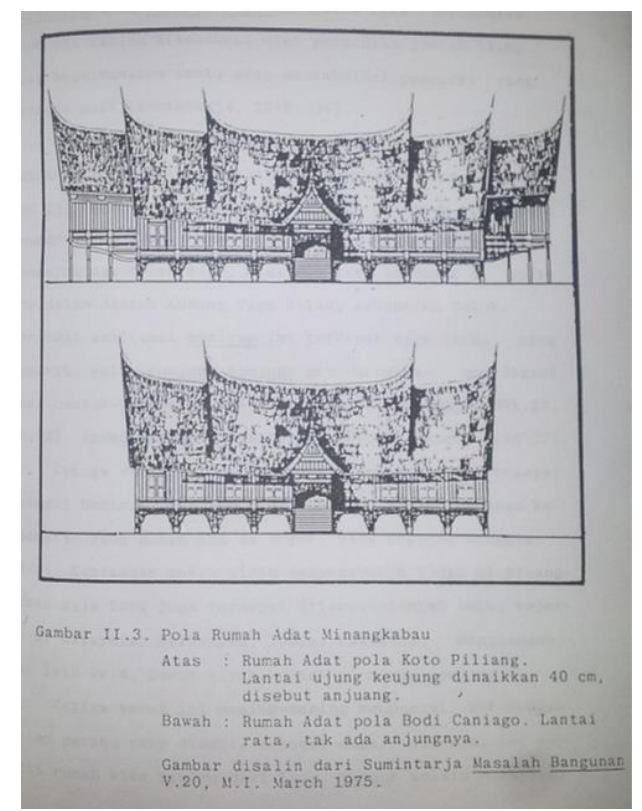

Gambar 2 Pola rumah adat Minangkabau (Ibenzani 1985)

Sedangkan Ibenzani (1985) merangkum pola arsitektur Rumah Gadang berdasarkan ciriciri atau identitas rumah melalui sistem kelarasan, dimana kelarasan Koto Piliang dengan prinsip titiak dari ateh (menitik dari atas) memerintah secara otokratis memiliki anjung dibagian ujung kanan dan kiri rumah, lebih tepatnya dinaikan selangkah sekitar $30-40 \mathrm{~cm}$, sedangkan kelarasan Bodi Caniago mambasuik dari bumi (membersit dari bumi) memerintah secara demokratis, yang terlihat ciri khas dari rumahnya tidak memiliki anjungan, tetapi struktur dari bangunan mempunyai kesamaan. Maka kedua laras tersebut mempengaruhi bentuk pola sebagai identitas pemilik dari karakter rumahnya. 


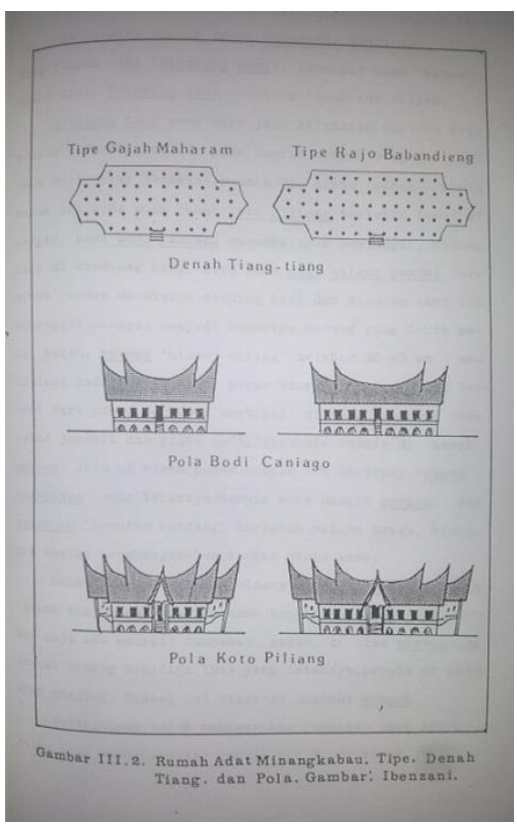

Gambar 3 Denah tiang, tipe dan pola Rumah Gadang (Ibenzani 1985)

Secara teoritis ruang-ruang kehidupan, seperti luas dan bentuknya diatur berdasarkan pembagian tanah oleh suku Minangkabau lama. Sedangkan bentuk bangunan serta denah ruang diatur menurut tradisi setempat atau kesepakatan ninik mamak nagari di Minangkabau. Ini adalah sebuah bentuk kebudayaan lama yang mungkin tidak kelihatan lagi pada masa kini yang sekarang lazim disebut dengan propinsi Sumatera Barat (Couto 2008, 64).

Walaupun pada awalnya masyarakat Minangkabau lama mungkin memiliki kesamaan dalam mengatur bentuk bangunan dan fungsi tiang serta teknik membangunnya. Akhirnya sesuai dengan perjalanan sejarah akan terdapat perbedaan-perbedaan. Perbedaan itu dipengaruhi oleh keyakinan, legenda atau mitos atau oleh tradisi lokal yang tumbuh pada masing-masing nagari. Perubahan itu dipengaruhi oleh perubahan sosial, akulturasi budaya, tuntutan baru, fungsi bangunan, lingkungan dan iklim. Misalnya antara bangunan di daerah pesisir dan di daerah pegunungan (darek). Yaitu bangunan tradisi yang berasal dari Luhak Nan Tigo yang lebih sederhana.

\section{Elemen Visual dan Kesalahan Presepsi}

Imajinasi visual selama ini yang umumnya dikenal adalah adalah dari bentuk gonjong, hampir semua objek-objek visual sebagai kode sosialnya adalah dari perubahan bentuk gonjong. Seperti dari hasil dokumentasi berikut ini :

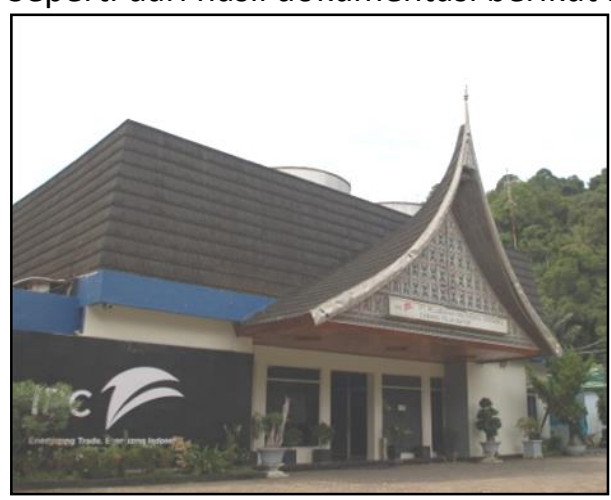

Gambar 4 Gonjong cula badak gedung perkantoran (Fariko, 2017) 


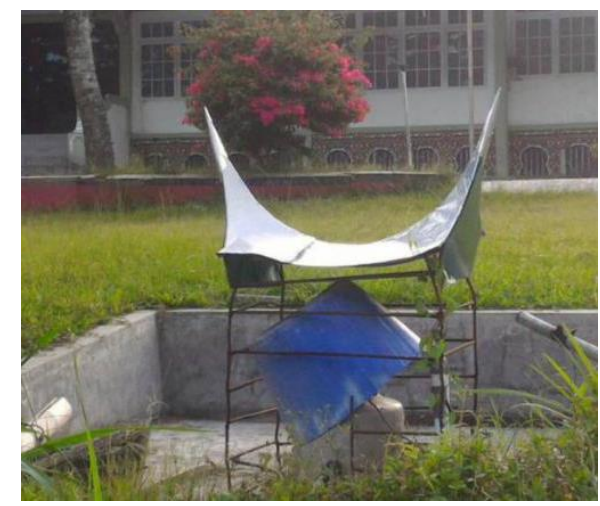

Gambar 5 Gonjong sebagai peneduh mesin pompa air. (Fariko, 2017)

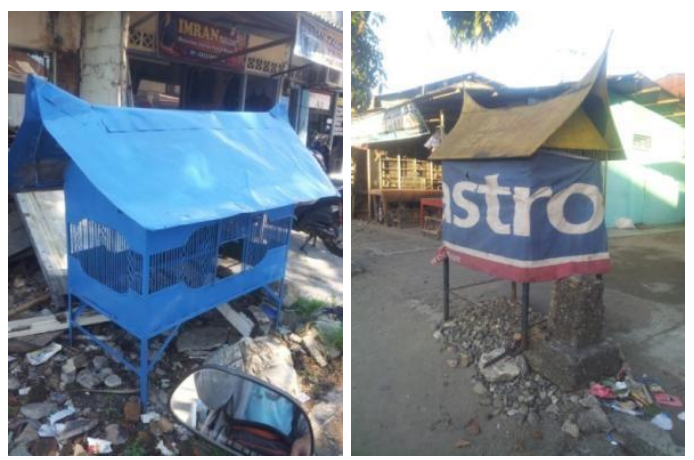

Gambar 6 Gonjong sebagai atap kandang. (Fariko, 2017)

Prilaku desain yang stereotip menjadikan sebuah ikon penting dari rumah adat Minangkabau untuk kepentingan estetika sebagai identitas yang menampilkan elemen gonjong pada desainnya. Fenomena ini Couto (2008) menjelaskan sebuah pandangan stereotip adalah suatu gagasan atau gambaran distandardisasikan atau disederhanakan secara berlebihan, berpegang kepada seseorang atau kelompok lain. Dari sumber foto yang penulis dapatkan di atas menurut penjelasan dari hasil stereotip dari kode-kode visual sosial Minangkabau. Banyak lagi contoh yang dapat dilihat dilingkungan sekitar, sebagai kode visual yang menampilkan identitas dari orang Minangkabau, seperti merek rumah makan dan sebagainya.

Sedangkan dalam pola arsitektur Rumah Gadang yang memiliki konsep pembentukan ruang dalam, sebagai teori tanda dan orientasi dalam pembangunan rumah adat Minangkabau. Dikarenakan tanda ruang, tempat tersebut melekat sebagai identitas tersendiri, batas-batas wilayah. Dari segi visual Rumah Gadang juga memiliki kajian konsep teori golden section. Golden section dapat dilihat dari bentuk alami lingkungan dan alam semesta, baik itu disengaja ataupun tidak disengaja yang menciptakan visual yang secara psikologis menyenangkan ketika dilihat oleh mata. Golden Section secara visual tidak memiliki ukuran yang seimbang secara teori tetapi ketika dilihat oleh mata memberikan efek yang seimbang dan harmonis bagi mata sehingga nyaman untuk dilihat.

\section{Revitalisasi Rumah Gadang}

Revitalisasi adalah suatu proses atau cara dan perbuatan untuk menghidupkan kembali suatu hal yang sebelumnya terberdaya sehingga revitalisasi berarti menjadikan sesuatu atau perbuatan untuk menjadi vital, sedangkan kata vital mempunyai arti sangat penting atau sangat diperlukan sekali untuk kehidupan dan sebagainya. KBBI Online https://kbbi.web.id/revitalisasi akses (22 Agustus 2017).

Dari hasil sumber kajian tentang konsep revitalisasi ini, maka konsep garapan untuk 3D puzzle nantinya akan menghidupkan kembali rasa peduli untuk mempelajari kearifan lokal 
berupa pembangunan Rumah Gadang yang kaya akan makna dan filosofinya. Seperti halnya untuk membangun Rumah Gadang tersebut akan dibutuhkan rasa kebersamaan dan gotongroyong masyarakat.

\section{Rancangan Konsep Garapan \\ Tinjauan karya LEGO}

Lego adalah sejenis alat permainan bongkah plastik kecil yang digubah oleh seorang pengrajin kayu yang benama Ole Kirk Chiristiansen. Nama Lego merupakan singkatan kata dari Denmark "Leg Godt" yang artinya bermain dengan baik, begitu cita-cita perusahaan itu bermula. Founded in 1932, and based on the iconic LEGO brick, it is one of the world's leading manufacturers of play materials, Lego (2016). Mainan intelegensi yang terkenal di dunia khususnya dikalangan anak-anak atau remaja, tidak pandang lelaki ataupun perempuan. Bongkah-bongkah ini serta kepingan lain bisa disusun menjadi model apa saja. Bermain lego juga dapat mempengaruhi perkembangan kognitif anak prasekolah (4-5 tahun) dalam hal kemampuan tilikan ruang, berpikir logis, mengingat, dan mengamati dengan cepat dan cermat (Utami, Qur'aniati, and Kusuma 2017).

Lego merupakan permainan yang bersifat membina keterampilan dan rangsangan bagi kreatifitas anak, karena melalui eksperimentasi dalam bermain anak akan menemukan bahwa merancang sesuatu yang baru dan berbeda dapat menimbulkan kepuasan (Hurlock 2005). Sedangkan rancangan prototype 3D puzzle Rumah Gadang, terbuat dari bahan dasar kayu dan acrylic. Dalam hal ini pembuatan bongkah pasang plastik dengan bongkar pasang kayu secara teknik hampir bersamaan namun dari segi bentuk dan hasil serta bahan sangat berbeda.

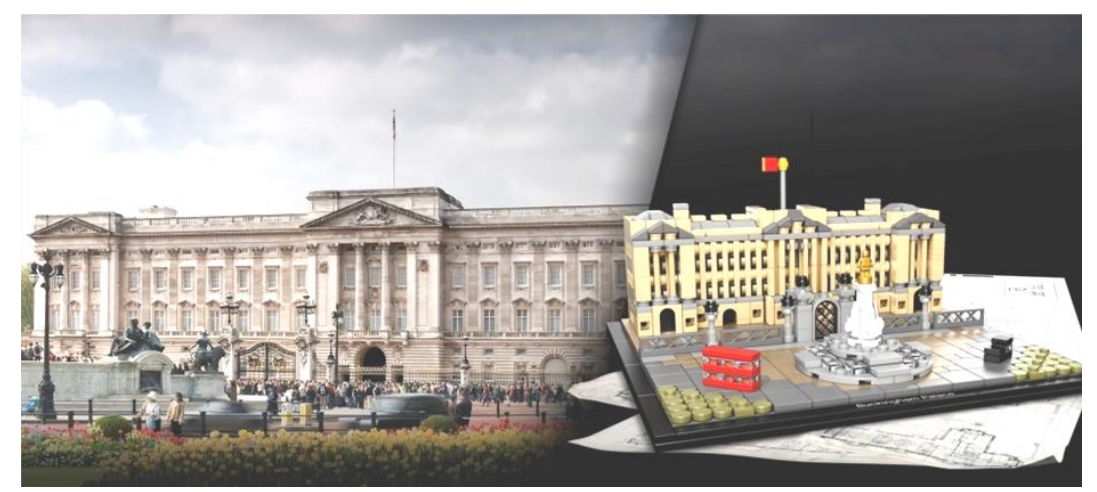

Gambar 7 Tampilan LEGO dengan Jenis Arsitektur (Unduh : image.google/lego, 2016)

Konsep permainan lego yang menciptakan jenis arsitektur ini menjadikan situs bangunan bersejarah sebagai ide penciptaannya, dimana setiap bangunan bersejarah dunia telah dibuat menjadi bagian produk permainannya. Serta nama bangunan, sejarah, maupun nama arsitek yang membuat bangunan tersebut terlampir juga pada buku panduan atau manual book yang disajikan oleh Lego. Begitu juga pada perancangan 3D puzzle Rumah Gadang ini nantinya, dimana arti dan pemaknaan bagian-bagian Rumah Gadang Rajo Babandiang juga terlampir pada manual book.

Konsep Umum

Menurut Ediwar (dalam Rasmida 2015, 40) sehubungan dengan ide tersebut maka dalam perwujudan karya yang diinginkan adalah menampakan nilai-nilai, pendidikan, patriotisme, keuletan, inovasi, yang berkaitan dengan logika, etika, dan estetika. Nilai logika mendasari kajian ilmu yang bersifat rasional dan empirik, yang membentuk keterampilan teknik, sedangkan nilai etika adalah masalah ukuran salah dan benar, baik dan buruk, berhubungan dengan ajaran religi, moral akhlak, tata krama, sopan santun, dan lain-lain. Adapun nilai estetika mendasari bentuk bentuk sintetik baru yang lebih indah dan memuaskan. 
Rancangan konsep garapan merupakan ide awal untuk menuju penciptaan karya. Penciptaan prototype atau purwarupa 3D puzzle Rumah Gadang ini, tidak hanya permainan bongkar pasang saja, sama halnya dengan mengembangkan kecerdasan spasial ruang visual Berdasarkan pendapat Winoto, Aufa, and Anwar (2020) menyimpulan bahwa kecerdasan spasial adalah kecerdasan yang dimiliki oleh setiap individu dalam bentuk kemampuan untuk memandang warna, garis, bentuk dan ruang, serta dapat memahami visual serta sifat-sifat keruangan. Akan diterapkan pada setiap elemen-elemen atau bagian puzzle ini memiliki penomoran atau kode tertentu, untuk berfungsi sebagai keterangan makna dalam bagian pada bangunan Rumah Gadang, dibuat sesuai dengan kaidah desain. Mulai dari pembuatan sketsa, proses digitalisasi 3D, pembuatan prototype sebagai media utama, perancangan packaging atau kemasan, manual book, dan media pendukung lainya berupa stiker, kartu nama, baju, launching pameran.

\section{Konsep Verbal}

Bentuk verbal pada perancangan 3D puzzle Rumah Gadang ini adalah pada sebuah konsep yang komunikatif dimana Rumah Gadang yang dikenal bukan sekedar citra identitas lokal masyarakat Minangkabau, tetapi sedikit lebih detail atau mendalam tentang bagian struktur bangunan. Konsep yang akan ditanamkan dalam puzzle nantinya adalah dimana setiap bagian (komponen dari puzzle) akan dituliskan ke dalam rancangan media pedukung berupa buku panduan pemasangan.

\section{Konsep Visual}

Budaya visual dalam konsep visual. Seseorang membaca dan memaknai apa yang dilihatnya, dia menafsirkan sesusai dengan pengalaman visualnya atau pembelajaran yang diperolehnya dari melihat (Couto 2008, 5). Melalui bentuk visual dan imaji visual, 3D puzzle Rumah Gadang menjadi bahasa visual yang dilihat dan digunakan oleh penggunanya, maka setiap komponen puzzle akan diberikan rancangan simbol untuk menjelaskan konsep verbal.

Kencendrungan pendidikan pada umumnya, terbiasa dilatih untuk mengenali bahasa simbol dan berpikir abstrak (melatih otak kiri), dan jarang yang memahami bahwa bahasa visual itu juga harus dipelajari (melatih otak kanan). Fenomena sosial dalam hal budaya visual memang unik perlu dipelajari lebih dalam. Sebab sering masyarakat menafsirkan tampilan visual secara stereotip dan negatif. Perbedaan kebudayaan dapat menyebabkan produk visual seperti hasil seni, desain, bangunan, pakaian ditafsirkan dengan cara berbeda.

Dapat dikatakan bahwa kebudayaan Minangkabau bisa ditafsirkan dari pemikiran dan segala makna, melalui penandaan pada Rumah Gadang dengan ukirannya, seperti motif tenunan, ataupun pidato adatnya. Konsep budaya ini dapat juga dipakai kedalam bentuk ilmu seni rupa dan desain, yang mengambarkan alam pikiran masyarakat tradisional Minangkabau. Misalnya kreasi bangunan tradisional-modern yang dibuat selama ini dianggap sangat harfiah dan ikonik, justru akan menurunkan nilai-nilai kreativitasnya. Karena dianggap sebagai peniruan tipologi atau gaya bangunan lama, rancangan bangunan seperti ini dapat dianggap tidak kreatif. Dengan konsep ini ternyata ciri bangunan rumah adat Minangkabau yang baru tidak seharusnya selalu bergonjong sebagai simbol ke-minangannya.

Maka fenomena tersebut telah menjadi tafsiran tersendiri bagi budayawan dan seniman di Sumatera Barat ini, mereka menghadirkan beberapa rumusan untuk menghadirkan kembali budaya visual Minangkabau tersebut ke dalam bentuk visual yang ada di Museum Adytiawarman, berupa miniatur bangunan Minangkabau dan suasana nagari ke dalam bentuk diorama. 


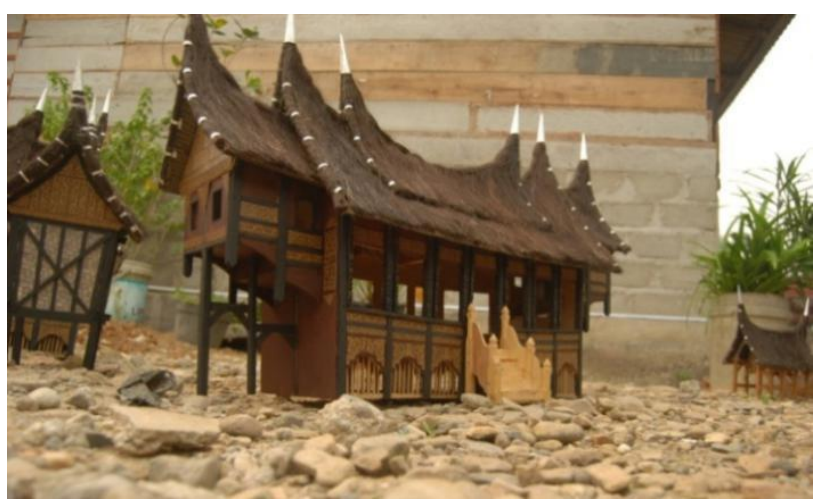

Gambar 8 Karya miniatur diorama Rumah Gadang museum Adityawarman. (Martal, 2016)

Miniatur Rumah Gadang dalam project museum ini merupakan sumber ide untuk pembuatan 3D puzzle Rumah Gadang yang dapat bongkar-pasang, sehingga setiap elemen bangungan ini dibuat rancangan sekatnya. Sketsa dari eksperimen pertama dilakukan membuat lantai dan tiang-tiang, dengan jarak serta ukuran tiang masih dalam perkiraan pengkarya, maka dari rancangan awal ini, terlihat bagaimana teknik pemasangan puzzle nantinya, yang setelah itu pengkarya melakukan pengukuran ke lokasi Rumah Gadang Sungai Beringin yang terdapat di daerah Payakumbuh.

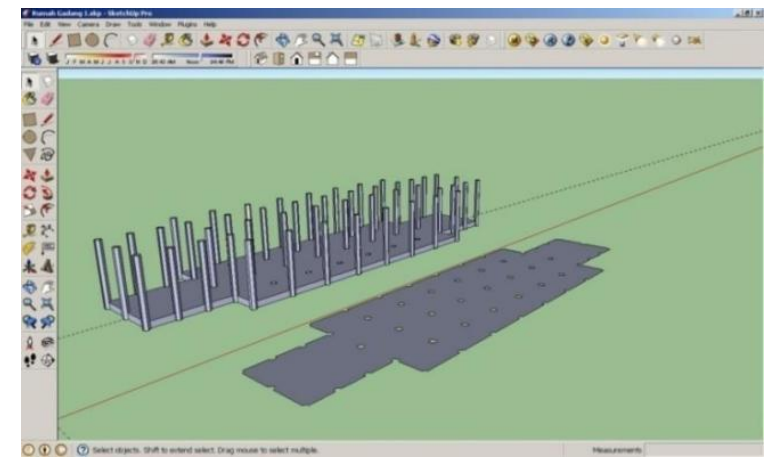

Gambar 9 Eksperimen pertama layout struktur tiang dan lantai puzzle (Fariko, 2017)

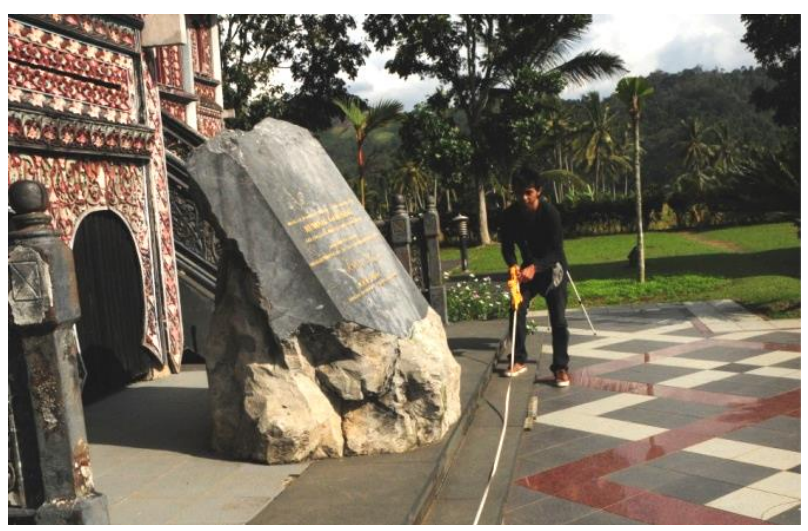

Gambar 10 Proses pengumpulan data di Rumah Gadang Sungai Beringin (Fariko, 2017)

Setelah mendapat ukuran, pengkarya kembali mencocokkan ukuran Rumah Gadang tersebut dari sumber penelitian dari buku atau karya disertasi yang telah diteliti oleh orang sebelumnya, sehingga nilai satuan yang didapatkan oleh pengkarya tidak jauh berbeda dari sumber literasi tersebut, dimana salah satunya jarak tiang ke tiang yang pengkarya temukan 
dengan ukuran $340 \mathrm{~cm}$, dengan total keseluruhan panjang Rumah Gadang Sungai Beringin tersebut adalah 37 meter, dan lebarnya 10 meter.

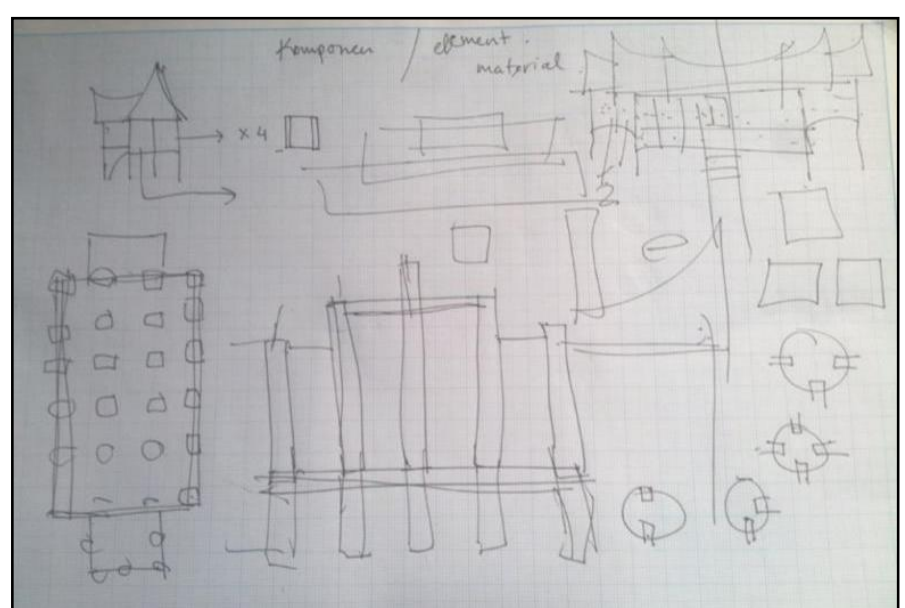

Gambar 11 Gambar kerja rancangan pada komponen puzzle (Fariko, 2017)

Tahapan rancangan dari sketsa manual, pengkarya membuat rancangan pada aplikasi desain menggunakan software desain grafis dan desain 3D graphic, google sketchup. Pengkarya telah membuat perbandingan dari ukuran asli dari Rumah Gadang Sungai Beringin di Payakumbuh. Setelah mengalami perenungan, dimana metode Alua dan Patuik dari istilah Minangkabau, yakni teori yang dipakai oleh Tukang Tuo atau tukang ahli. pengkarya banyak menemukan kejanggalan terhadap struktur bangunan, seperti contoh; bangunan Rumah Gadang Sungai Beringin yang asli ini, tonggaknya sudah dibuat dari semen, jumlah ruangan 7 bilik, dan bangunan ini bersifat atau berguna sebagai gedung pertemuan untuk destinasi wisata, acara pemerintahan, dan museum.

\section{Konsep Perancangan}

Konsep perancangan 3D puzzle Rumah Gadang, mengakar dari prinsip gotong royong batagak rumah sebagai prosesi acarat adat, dan juga menerapkan prinsip praktik alua jo patuik, secara kebersamaan. Maka, semangat untuk merangkai puzzle Rumah Gadang ini akan menjadi sebuah nilai yang tersirat dalam revitalisasi kearifan lokal, dikarenakan di setiap komponen dan lempengan puzzle Rumah Gadang ini akan dibubuhkan kode yang akan dijelaskan beserta arti dan makna elemen Rumah Gadang yang tercantum pada buku panduan atau manual book.

Dari merangkai puzzle Rumah Gadang ini akan memunculkan kreatifitas dan intelegensi pikiran, sehingga terciptalah imajinasi untuk berkeinginan mendirikan Rumah Gadang sendiri melalui media permainan ini, sedangkan prototype ini memiliki warna yang putih dari bentuk tiang dan dinding, dan warna hitam untuk atap gonjong, yang bertujuan agar pengembangan kreativitas bagi pengguna bisa melakukan eksperimen sendiri untuk membuat proses pewarnaan tiang, maupun penambahan motif-motif ukiran pada dinding puzzle Rumah Gadang tersebut menggunakan spidol, cat ataupun stiker. Kemasan untuk prototype ini disajikan semenarik mungkin mudah dibawa, dan aman dari goncangan maupun tumpukan, yang terbuat berbahan kayu ringan, sehingga mengangkat nilai elegant dari puzzle Rumah Gadang ini. 
Penyaringan idea tau disebut juga dengan brainstorming merupakan tahapan yang dilakukan setelah data yang diperlukan terkumpul. Brainstorming berfungsi untuk memilahmilah data dan menseleksi data yang penting dari pemetaan ide.

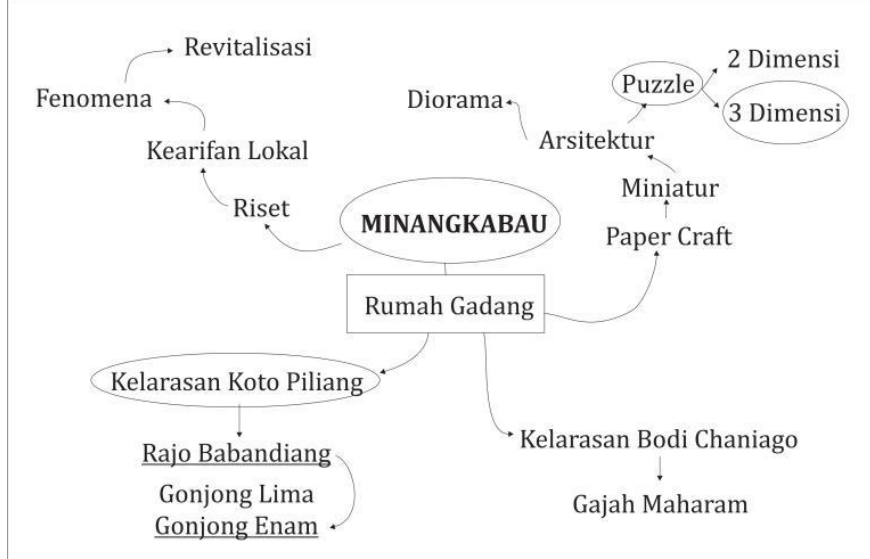

Gambar 12 Brainstorming data 3D puzzle Rumah Gadang. (Fariko, 2017)

\section{Visualisasi}

Langkah awal dari proses perancangan 3D puzzle Rumah Gadang ini, tahap yang dilalui dari hasil riset adalah sketsa, dan pemindahan sketsa ke aplikasi digital menggunakan software Google SkecthUp. Ulasannya sebagai berikut.

\section{Sketsa}
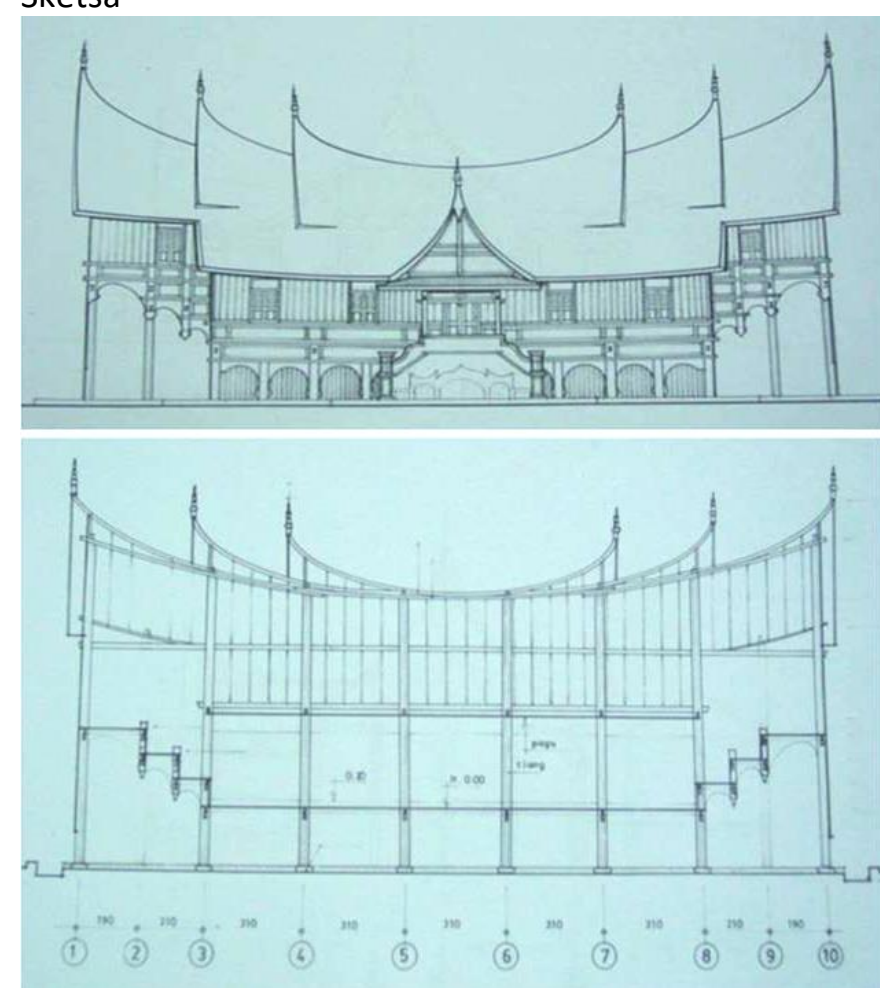

Gambar 13 Bentuk Rumah Gadang baanjuang kelarasan Koto Piliang. (Jonny Wongso, 2017)

Bentuk gambar tampak depan dari Rumah Gadang ini, lanjut ke proses sketsa denah lantai, atau lanjar puzzle Rumah Gadang. Dimana sketsa denah lantai ini sekaligus menjadi gambar kerja untuk proses digital dan proses prototype. 


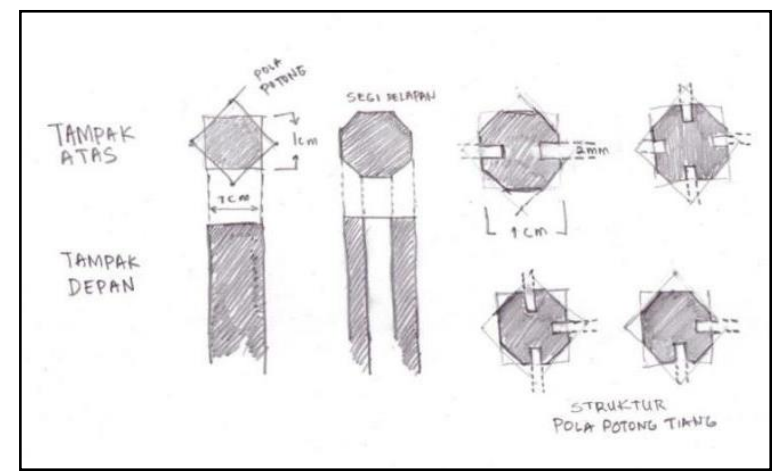

Gambar 13 Gambar Kerja Pembuatan Tiang (Fariko, 2017)

Setelah mendapatkan pola segi delapan bentuk tiang, maka selanjut adalah proses pemotongan struktur puzzle, dengan pola potong terdiri dari empat macam, pola tersebut didapatkan dari hasil gambar kerja denah lantai dan denah tiang, (gambar 13.) pola potong ini berfungsi untuk masuknya bagian elemen puzzle dinding Rumah Gadang. Dengan teknis yang tidak begitu rumit dalam pemasangan rangkaian dinding dan lain sejenisnya. Berikut bagaimana hasil sketsa cara pemasangan komponen puzzle yang berbahan akrilik.

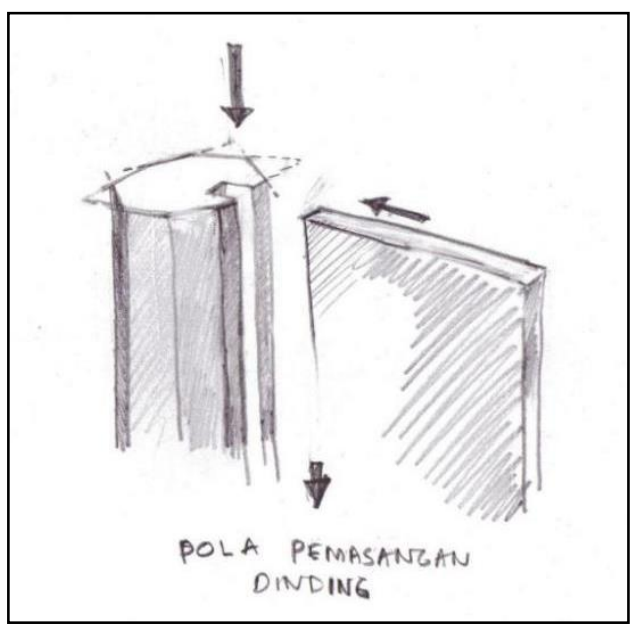

Gambar Langkah Kerja Pemasangan Elemen Dinding (Fariko, 2017)

Langkah pemasangan elemen dinding ini dengan cara memasukkan elemen dinding dan menggeser dari atas ke arah bawah yang telah tersedia pada tiang, sebut saja rel, dimana celah yang dibuat dengan ukuran $2 \mathrm{~mm}$. Rel ini berfungsi sebagai jalur dan penghubung dari tiang ke dinding ke tiang, dan seterusnya.

2. Proses digital

Proses digital berupa langkah berikutnya dari gambar kerja yang telah dibuat melalui aplikasi desain tiga dimensi, yang biasanya dipakai untuk merancang arsitektur bangunan, baik itu berupa interior maupun eksterior. Maka pengkarya memakai aplikasi open source dari perusahaan Google, dengan nama aplikasi Google SkecthUp. 


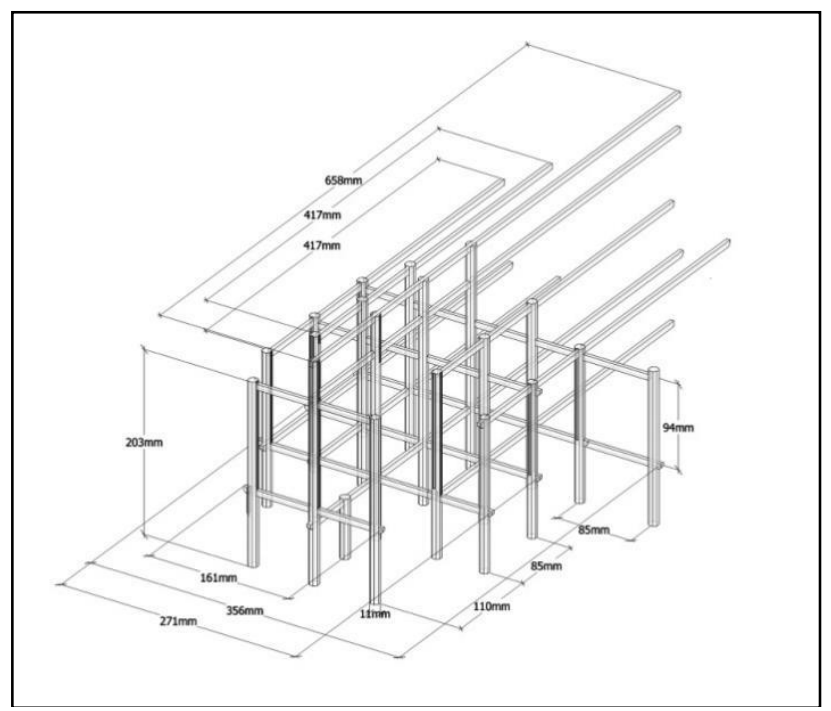

Gambar 15 Line Out, Tampilan Denah Tiang (Fariko, 2017)

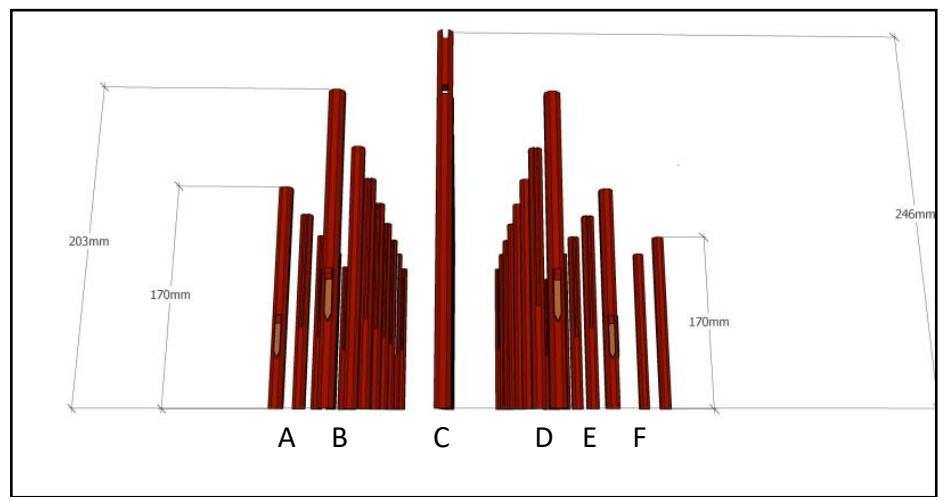

Gambar 16 Tampak samping Tiang (Fariko, 2017)

Tonggak ini berjumlah 40 unit, yang terdiri dari tiang A dan E dengan ketinggian $170 \mathrm{~mm}$ ada 12 unit, tiang $B$ dan tiang $E$ dengan tinggi $200 \mathrm{~mm}$ berjumlah 16 unit, tiang $C$ dengan tinggi $246 \mathrm{~mm}$ berjumlah 8 unit, sedangkan tonggak $\mathrm{F}$ untuk atap surambi berjumlah 2 unit dengan ukuran sama dengan tiang A dan E yakni $170 \mathrm{~mm}$.

Deretan tiang ini juga memiliki makna tersendiri, dimana nama tiangnya terdiri dari tiang panjang, tiang panagu alek, tiang biliak, tiang suko mananti, tiang salek. Berikut penjelasan berupa gambar di bawah ini.

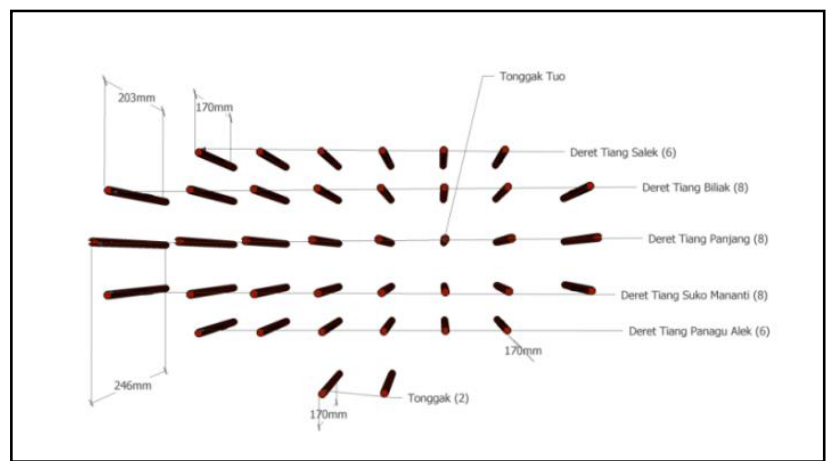

Gambar 17 Tampak Atas Susunan Tiang Rumah Gadang (Fariko, 2017)

Berikutnya perancangan bentuk susunan tiang berdasarkan pola gambar, dimana pola tersebut telah menjadi acuan untuk menyusun deret tiang, dengan memakai pengkodean 
berupa Huruf dan angka, dimana kode tersebut berdasarkan penamaan tiang dari Rumah Gadang itu sendiri. Yakni kodenya sebagai berikut :

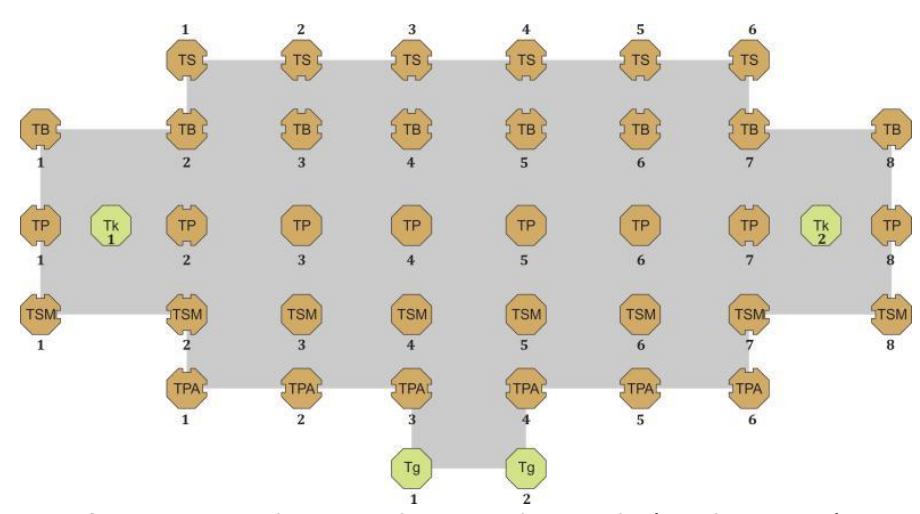

Gambar 18 Tampilan Denah Tiang dan Kode (Fariko, 2017)

Arti dan kode dari tiang puzzle Rumah Gadang sebagai berikut:

Tiang Panjang: TP berjumlah 8 unit

Tiang Salek : TS berjumlah 6 unit

Tiang biliak : TB berjumlah 8 unit

Tiang Suko Mananti : TSM berjumlah 8 unit

Tiang Tapi : TPA berjumlah 6 unit

Tiang Serambi : Tg berjumlah 2 unit adalah tiang tambahan.

Tiang Anjung : Tk berjumlah 2 unit, adalah tiang tambahan untuk menopang anjung.

\section{Lantai}

Lantai disebut juga dengan lanjar dalam pemetaan Rumah Gadang, dimana setiap baris ruang antara tiang memiliki penamaan tersendiri, dan memiliki ruang khusus untuk menempatinya. Seperti dari pintu masuk Rumah Gadang, di mulai dari ruang balai, labuah, bandua, dan biliak, serta kiri dan kanan adalah anjuang. Struktur dari pola puzzle dari komponen lanjar atau lantai, dimana bagian biliak, anjuang posisinya ditinggikan dari ruang utama Rumah Gadang.

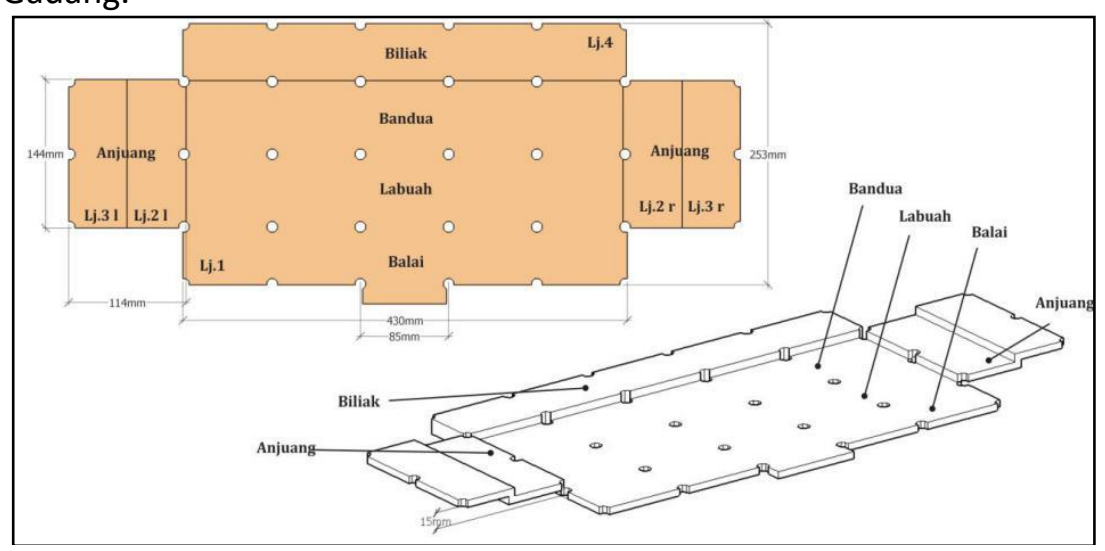

Gambar 19 Tampilan Denah Lantai (Fariko, 2017)

Makna penamaan dari lanjar lantai Rumah Gadang, setiap lanjar disebut juga dengan baris ruangan pada Rumah Gadang, yang menjelaskan posisi duduk untuk para tamu, berikut penjelasannya :

1. anjuang: Lantai kiri dan kanan rumah yang ditinggikan (ruang khusus).

2. biliak : Kamar Tidur (ruang pribadi).

3. Bandua : Sandaran duduk pada dinding sebelah dalam. (daerah khusus). 
4. Labuah : Jalan (tempat resmi).

5. Balai : Tempat umum atau publik

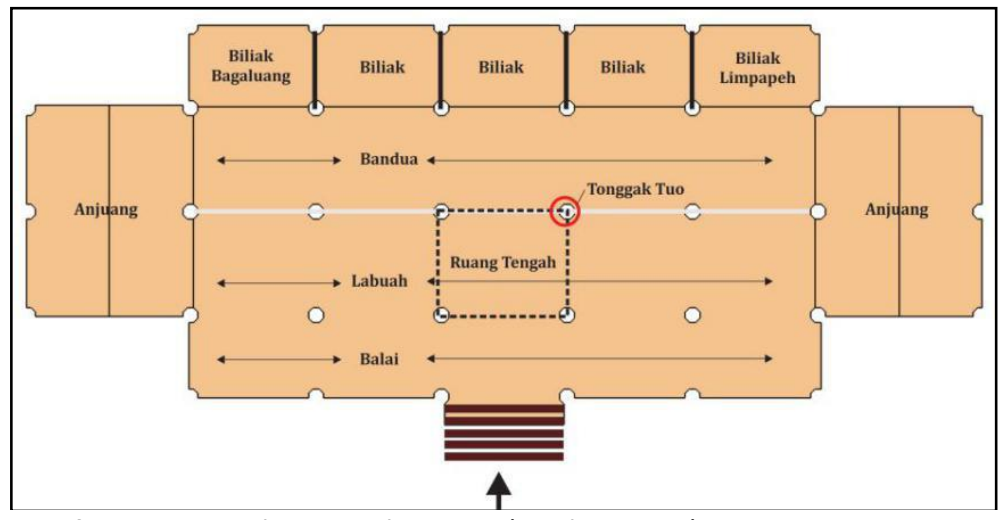

Gambar 20 Tampilan Denah Lantai (Fariko, 2017)

6. biliak : Kamar tidur.

7. biliak Bagaluang : Kamar tidur paling ujung.

8. biliak Limpapeh : Kamar tidur ibu pemilik Rumah Gadang

Plafon

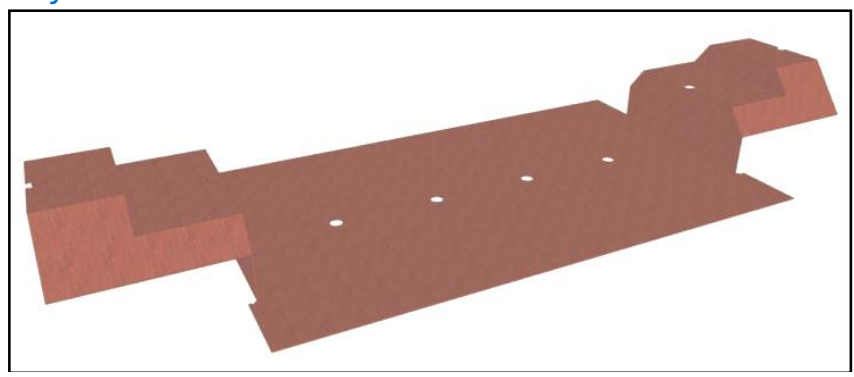

Gambar 21 Tampilan Bentuk Plafon (Fariko, 2017)

Plafon atau disebut juga dengan lotieng yang berfungsi untuk menutup bagian atas dari dinding rumah, yang terpasang di bagian bawah atap. Proses rangkaian plafon ini terdiri dari 13 bagian puzzle dengan menggunakan bahan acrylic.

Gonjong

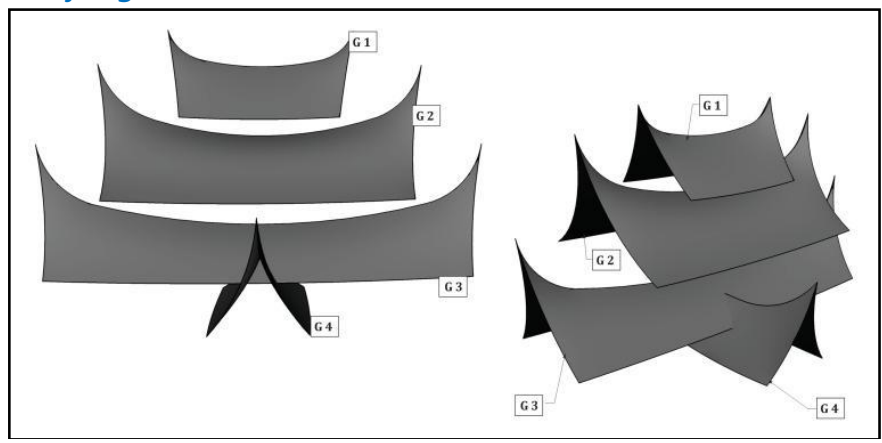

Gambar 22 Tampilan Bentuk Gonjong (Fariko, 2017)

Gonjong adalah ujung atap yang runcing dan melengkung, ciri khas bangunan Minangkabau. Bangunan rumah adat bagonjong enam adalah milik kaum keturunan Ninik Mamak menyandang gelar Sako Datuak Penghulu Kepala Suku, Pucuak, Pamuncak, pegawai 
adat dan milik kaum keturunan Bangsawan atau Raja-Raja. Pengkodean gonjong ini diberi kode huruf $\mathrm{G}$ dan penomoran 1 sampai dengan 4 .

\section{Singok}

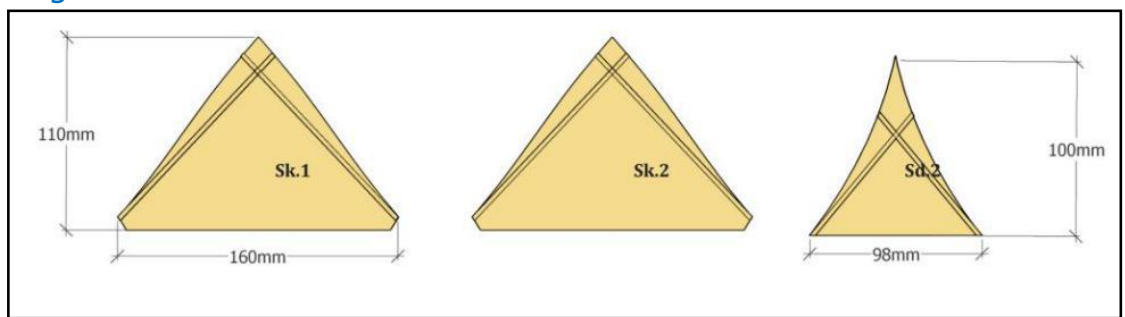

Gambar 23 Tampilan Bentuk Singok (Fariko, 2017)

Singok merupakan penutup atap dengan posisinya berada pada bagian atas dinding hari dan surambi, menggunakan kode huruf Sk.

\section{Dinding Tepi}

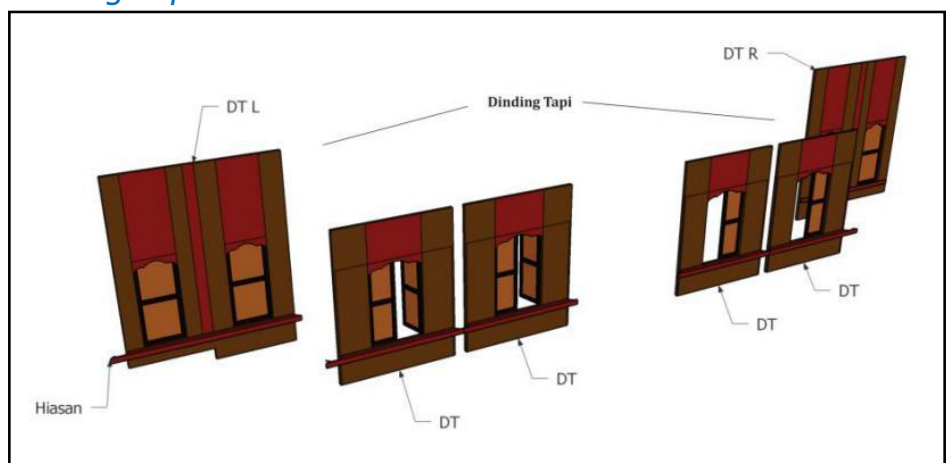

Gambar 24 Tampilan Pola Dinding Tepi (Fariko, 2017)

Ada 6 bagian dinding dengan kode DT, dimana dinding tepi bagian anjung memiliki bentuk yang unik, dan tinggi, dengan kode DT L artinya Dinding Tapi Left dan DT R yakni Dinding Tapi Right.

\section{Pola Pintu depan}

Bentuk pola pintu dan bentuk hiasan singok untuk atap dari surambi dimana jenjang naik ke Rumah Gadang sebagai berikut :

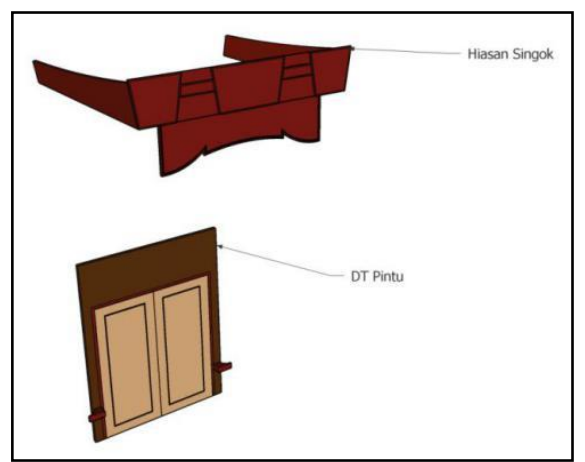

Gambar 25 Tampilan Pola Pintu dan Hiasan (Fariko, 2017)

Dinding Hari 


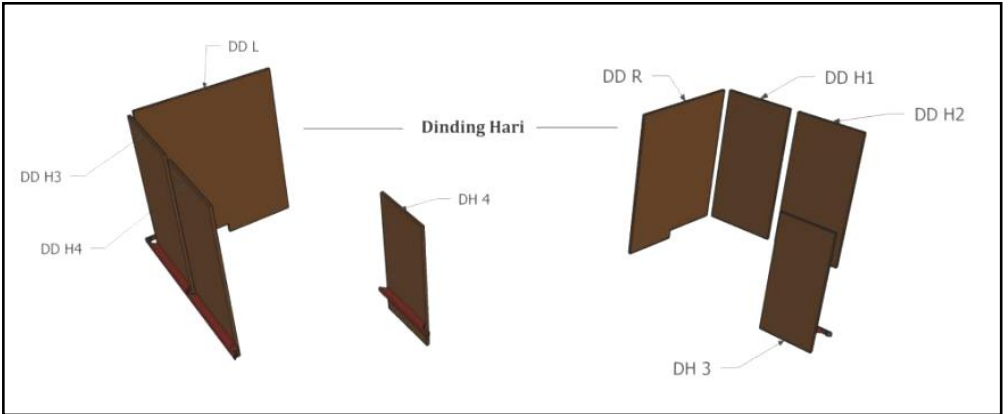

Gambar 26 Tampilan Pola Dinding Hari (Fariko, 2017)

Ada 10 bagian dinding dengan kode DD, DH berjumlah 4 unit, DD H berjumlah 4 unit, dengan kode DD L artinya Dinding Tapi Left dan DD R yakni Dinding Tapi Right. Yang terletak pada bagian anjung.

\section{Dinding biliak}

Dinding biliak atau disebut juga dengan kamar tidur, dimana setiap bagian komponen dinding akan diberikan kode DD, DH, DB, PB.

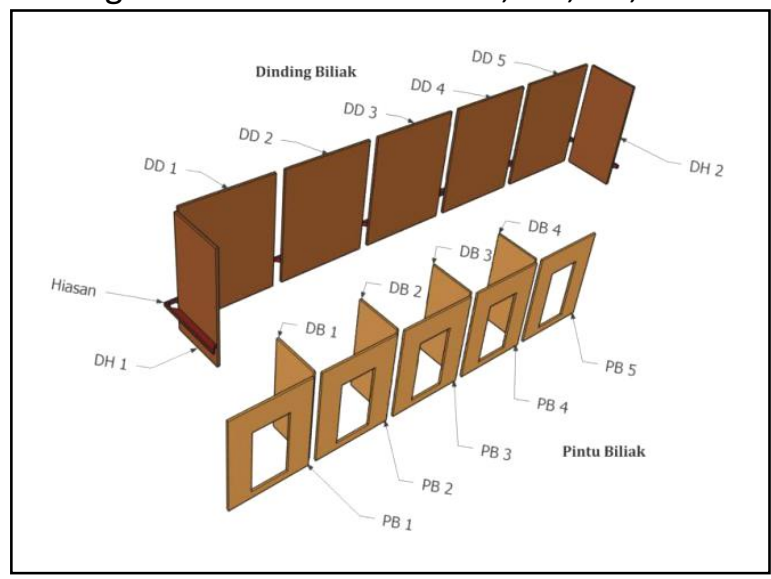

Gambar 27 Tampilan Pola Dinding biliak (Fariko, 2017)

Pintu biliak berjumlah 5 unit, serta sekat pembatas kamar, ada 4 unit sedangkan dinding biliak sekaligus bagian dinding belakang Rumah Gadang berumlah 5 unit, serta ada 2 unit Dinding Hari kiri dan kanan.

\section{Kamban-kamban}

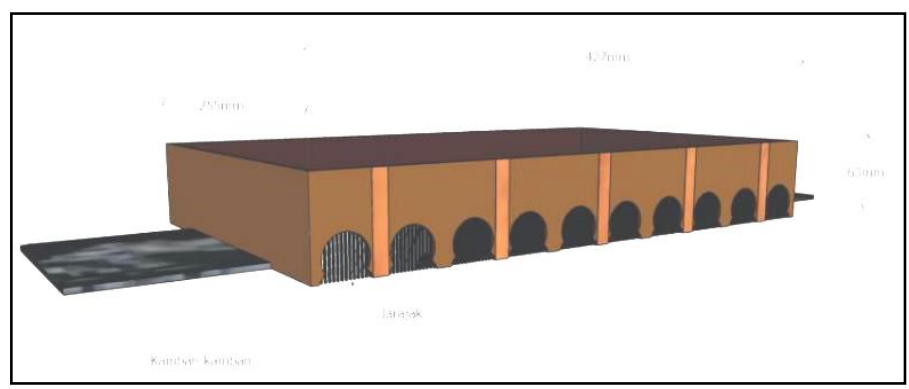

Gambar 28 Tampilan Pola Kamban-kamban (Fariko, 2017)

Kamban-kamban ini adalah ruangan yang berada di bawah Rumah Gadang, yang berfungsi sebagai kadang, dan ada juga yang memanfaatkan sebagai tempat menenun kain 
songket. Kamban-kamban ini terdiri dari 16 unit bagian puzzle yang mana kode dari kamban ini adalah $\mathrm{Kf}, \mathrm{Kb}, \mathrm{Kl}$, dan $\mathrm{Kr}$.

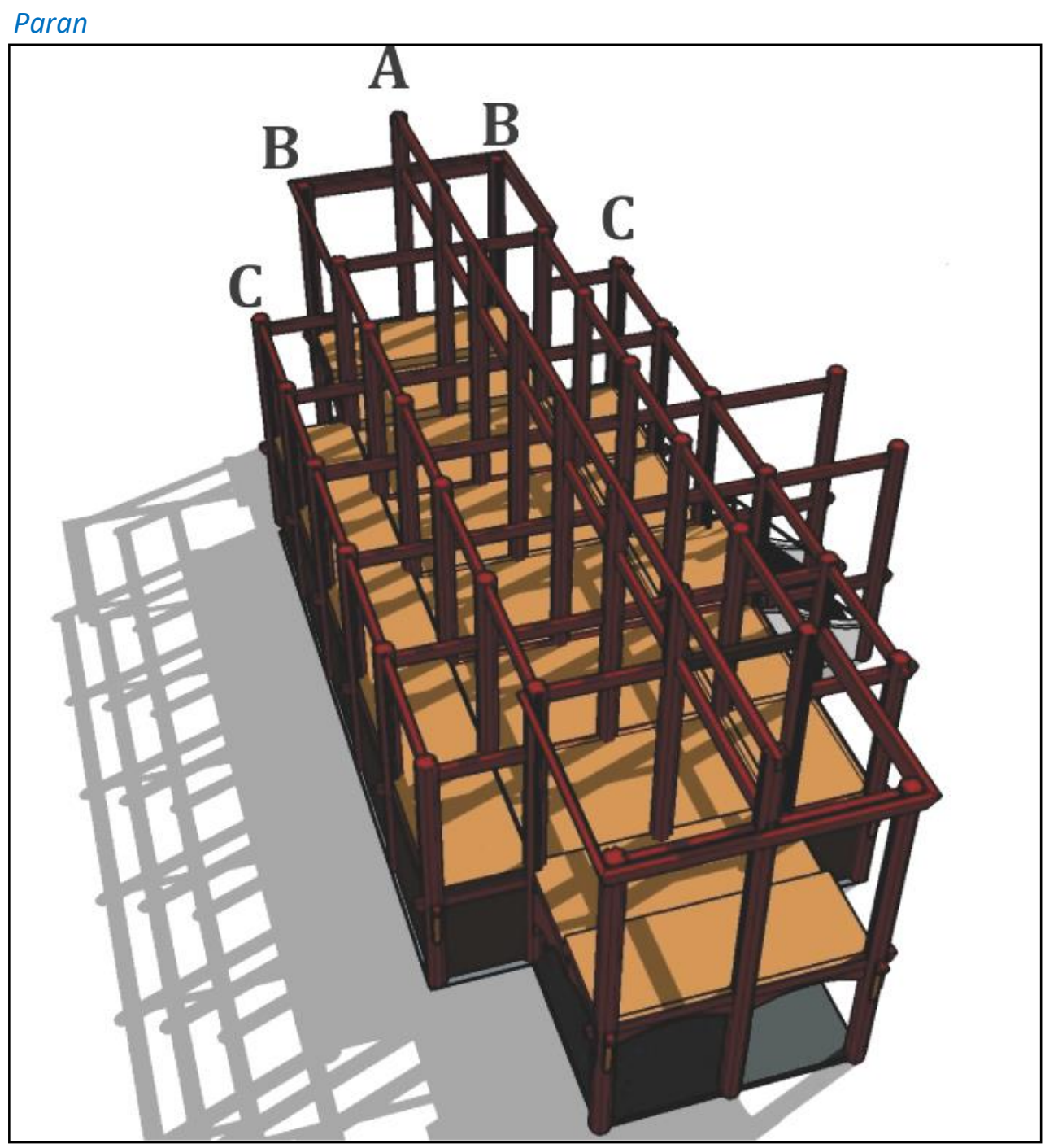

Gambar 29 Tampilan Pola Tiang Paran (Fariko, 2017)

Paran adalah kayu pasak yang melintang untuk mengkunci dan menembus tiang Rumah Gadang. Penyangga yang membentang diatas tiang ini untuk meletakkan atap Rumah Gadang, ada dua jenis Paran yaitu, Paran memanjang dan Paran melintang. Pola yang terlihat dapat menjadi acuan ketika pemasangan puzzle, maka setelah terpasang seperti ini, maka proses pengerjaan puzzle Rumah Gadang sudah 60 \%, maka pemasangan dinding dan atap adalah proses berikutnya. Pengkodean Paran terdiri dari kode A, B1 dan B2, C1, dan C2 


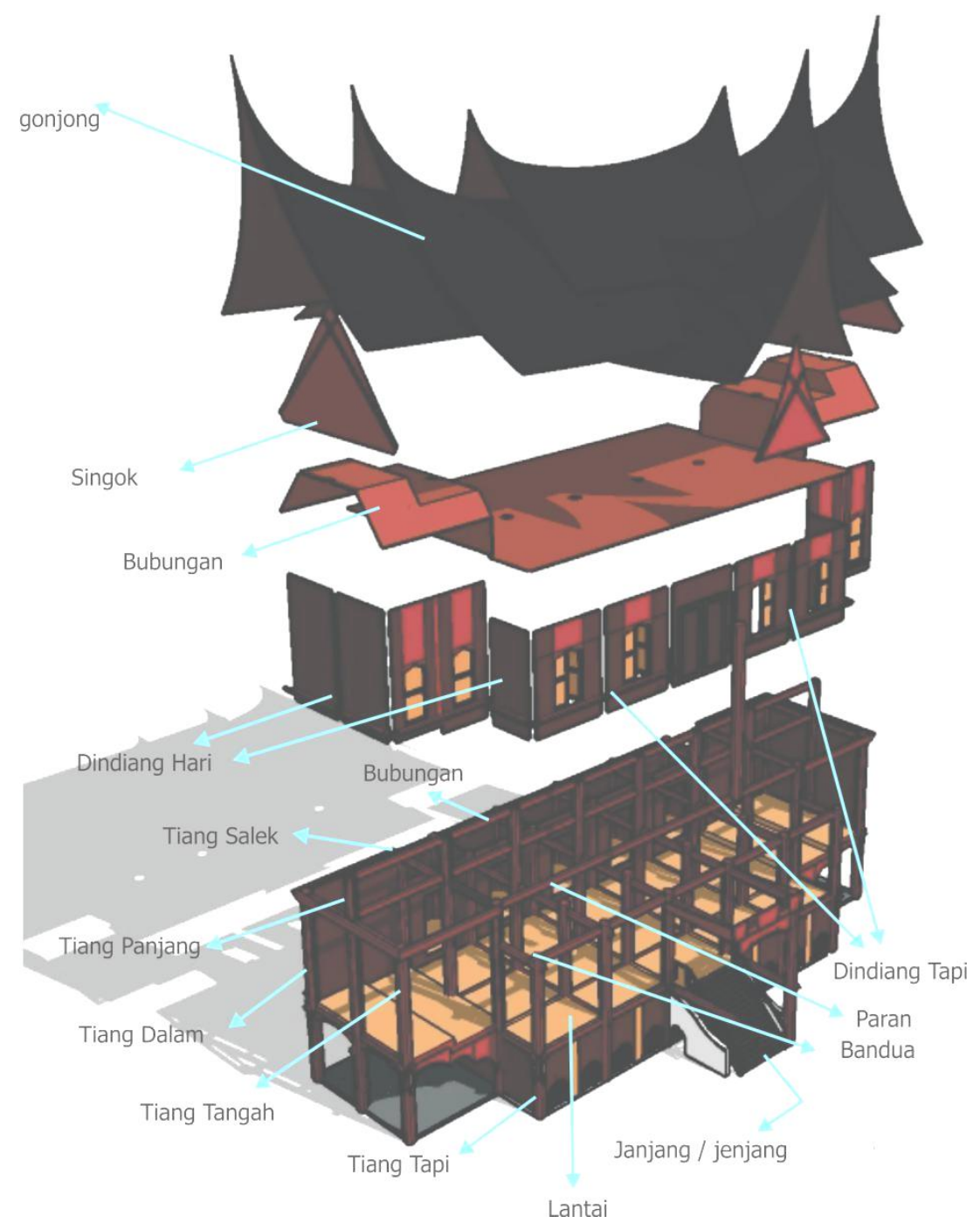

Gambar 30 Tampilan struktur puzzle Rumah Gadang (Fariko, 2017)

Gambar ini menjadi pedoman untuk membangun dan merangkai komponen puzzle Rumah Gadang.

\section{Proses Karya Utama}

Pengolahan Bahan

Bahan yang dipakai berupa kayu ringan yang di potong-potong dengan ketebalan $1 \mathrm{~cm}$, lalu kayu tersebut di buang setiap sudutnya sekitar $2 \mathrm{~mm}$, dengan hasil akhir menjadi tiang / tonggak pada puzzle Rumah Gadang yang berbentuk segi delapan. Selanjutnya pembuatan jalur untuk pemasangan dinding, dengan kedalaman $2 \mathrm{~mm}$, lebarnya juga $2 \mathrm{~mm}$.

Meramu bahan adalah proses sebagai pemilihan bahan yang ringan dan mudah untuk di olah, kayu yang digunakan adalah jenis kayu Jilutung yang merupakan sumber kayu yang ada di Sumatera Barat, dimana para pekerja seni menggunakan kayu ini untuk membuat ukiran, bisa juga dipakai untuk dinding ukiran Rumah Gadang yang asli.

Mesin scroll digunakan untuk memotong tiang puzzle Rumah Gadang, sedangkan mesin drill digunakan untuk membuat jalur pada tiang puzzle. 


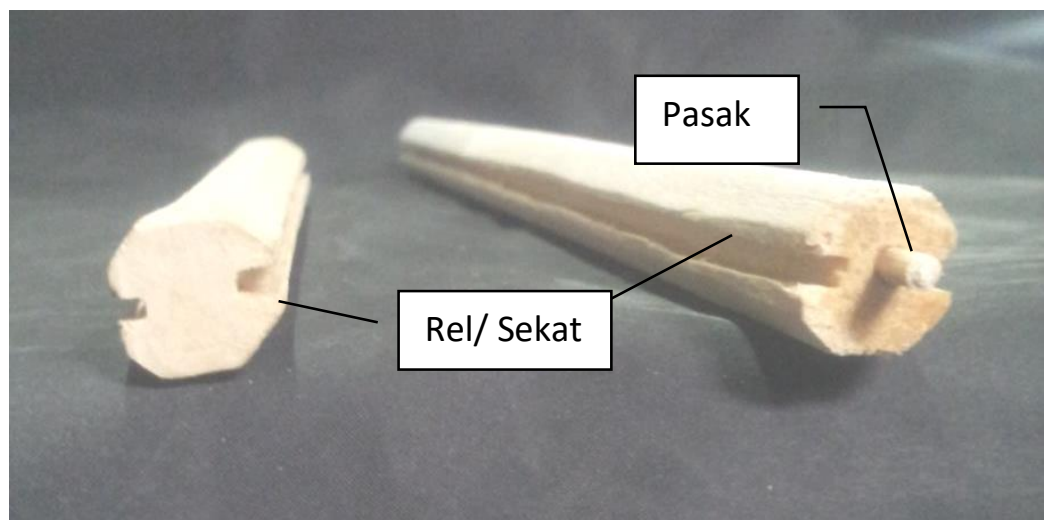

Gambar 31 Tiang dibuat Rel dan Pasak (Fariko, 2017)

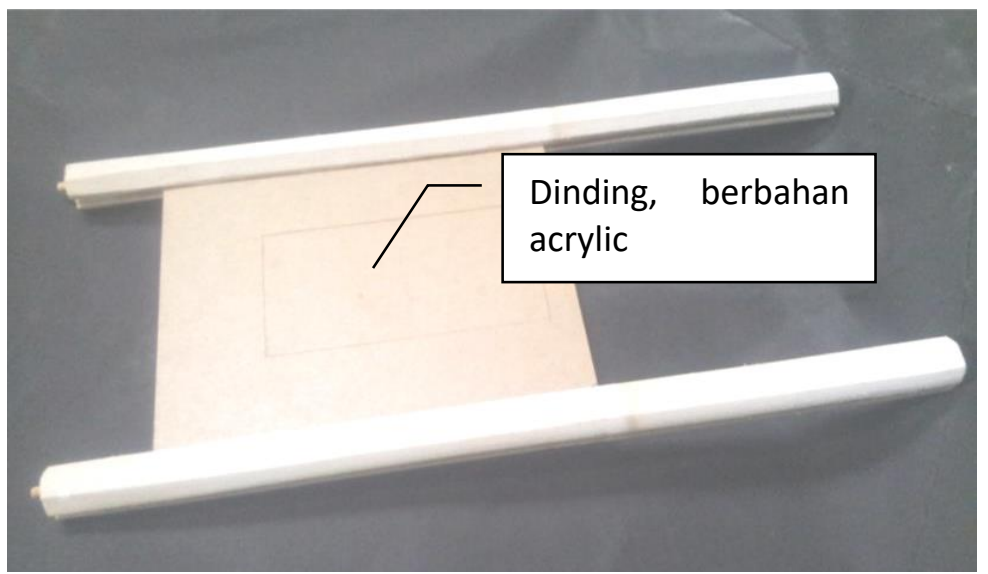

Gambar 32 Pemasangan Dinding puzzle (Fariko, 2017)

Pada gambar 31 dan gambar 32 menjelaskan tentang bagian komponen puzzle, dimana ada tiang dan pasak yang berbahan kayu, pada gambar 31 terlihat ada jalur tempat memasuki dinding, di gambar 32 adalah hasil yang telah terpasangnya jendela yang berbahan acrylic.

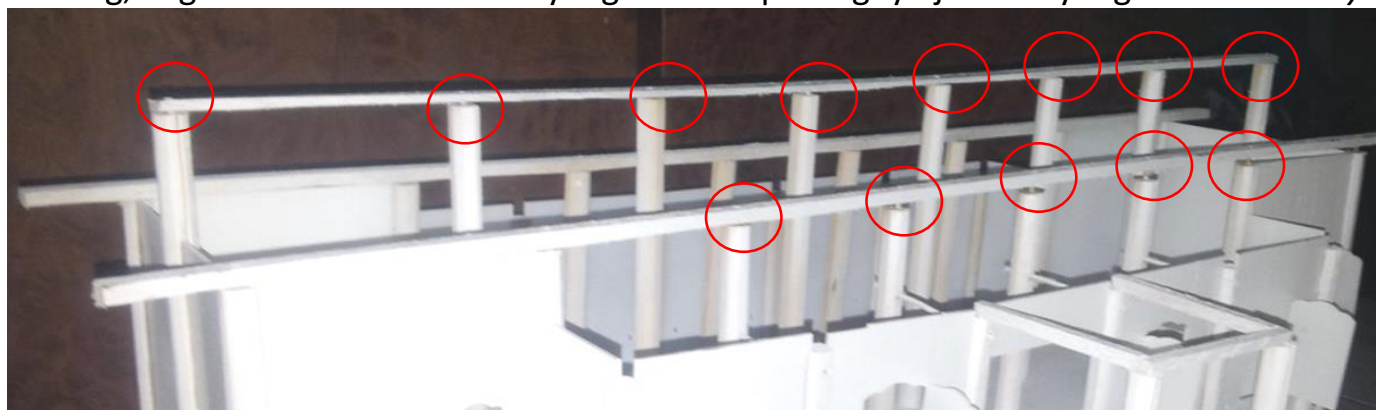

Gambar 33 Struktur pemasangan Paran pada pasak tiang (Fariko Edwardi, 2017)

Pemasangan Paran, atau kayu yang melintang di atas tiang, berguna untuk mengunci antar tiang puzzle. Terlihat pada gambar 31 yang menunjukkan pasak, sedangkan gambar 32 yang dilingkari merah, menjelaskan tentang Paran yang telah terpasang ke bagian pasak tiang. 


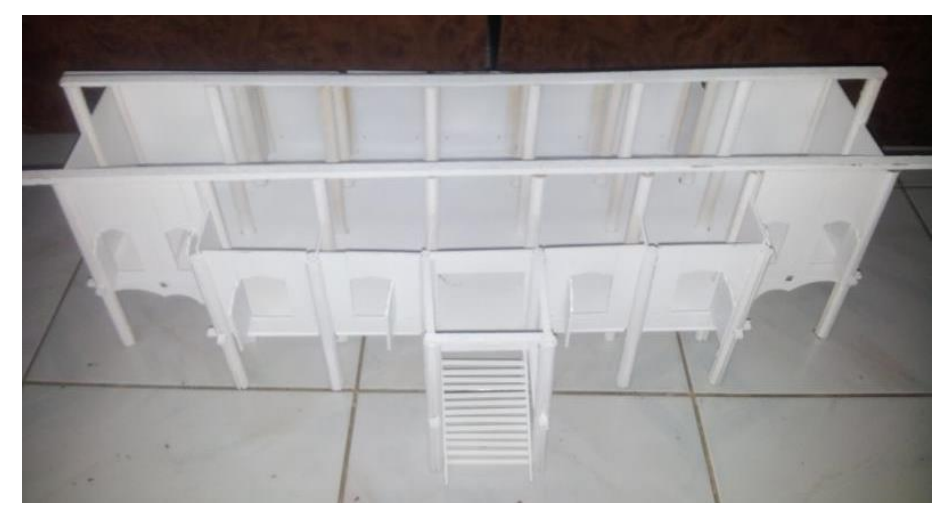

Gambar 34 Semua elemen dinding dan tiang sudah terangkai (Fariko, 2017)

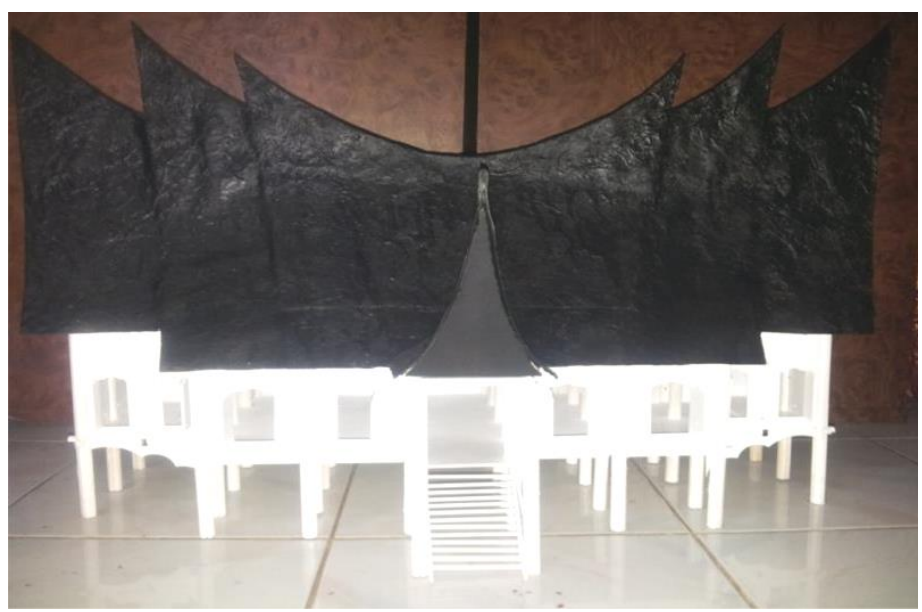

Gambar 35 Tampilan prototype 3D puzzle Rumah Gadang tipe Rajo Babandiang (Fariko, 2017)

Tampilan prototype 3D puzzle Rumah Gadang tipe Rajo Babandiang, ini adalah hasil akhir dalam pengerjaan prototype 3D puzzle tersebut. Maka setelah final maka karya ini akan belum lengkap jika tidak ada karya pendukungnya, desain dan media pendukungnya terdiri dari logo, buku panduan, dan media pendukung lainya berupa, stiker, packaging, dan media promosi lainnya

Desain Media Pendukung

Logo/sign mark

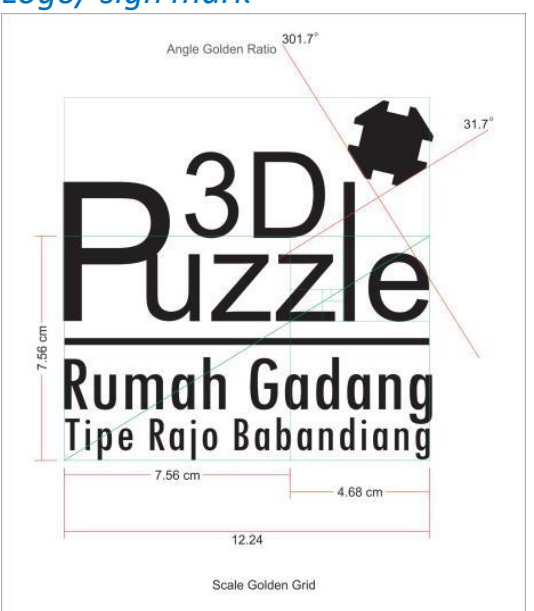

Gambar 36 Golden section grid, Logo 3D puzzle Rumah Gadang (Fariko, 2017) 
Perancangan logo sign mark 3D puzzle Rumah Gadang Tipe Rajo Babandiang, menggunakan jenis font Arial, Tw Cen MT Condensed, dan sign berupa bentuk puzzle dari tiang Rumah Gadang yang bersegi delapan. Pewarnaan logo, warna logo yang tidak jauh dari warna yang dipakai masyarakat Minangkabau sebagai bendera umbul-umbul (marawa) yakni warna hitam, merah dan kuning.

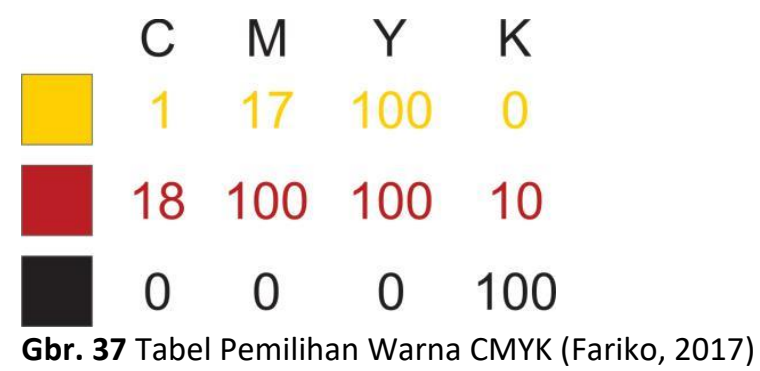

Setelah mendapatkan pemilihan warna dan kode warna CMYK, maka berikutnya mengaplikasikan ke logo 3D puzzle Rumah Gadang tipe Rajo Bandiang. Warna hitam menjadi warna pada typografi Rumah Gadang tipe Rajo Babandiang, warna merah pada 3D puzzle, dan warna kuning untuk sign puzzle. Yang memiliki psikologis warna terhadap manusia. Karena selain menimbulkan sensasi juga menimbulkan rasa senang dan tidak senang, sehingga penggunaan warna dalam desain komunikasi perlu memperhatikan faktor tersebut. Menurut Sanyoto dalam Trinanda (2013)Trinanda (2013) menjelaskan setiap warna dapat menimbulkan respon psikologis yang berbeda-beda, namun secara umum hubungan psikologis antara warna dengan manusia dapat dilihat sebagai berikut:

1. Warna merah

Power, energi, kehangatan, cinta, nafsu, agresif, bahaya. Warna merah mempunyai sifat sebagai pelambang kegembiraan dan keberanian.

2. Warna Hitam

Power, seksualitas, kecanggihan, kematian, misteri, ketakutan, kesedihan, keanggunan. Warna hitam melambangkan kesakralan dan kedudukan.

3. Warna Kuning

Optimis, harapan, filosofi, ketidak-jujuran, pengecut (untuk budaya barat), penghianatan. Warna kuning adalah warna paling bercahaya dan menarik minat seseorang. Warna kuning merupakan lambang keagungan dan kehidupan, mempunyai sifat kesaktian, kecemburuan dan keributan.

4. Warna Putih

Kesucian, kebersihan, ketepatan, ketidakbersalahan, steril, kematian. Warna putih mempunyai sifat bercahaya, sering diasosiasikan dengan hal-hal yang bernuansa kesucian dan kebersihan.

Warna dalam tradisi Minangkabau dipengaruhi oleh berbagai aturan dalam kebudayaan. Warna-warna tradisi dapat dideskripsikan berdasarkan penggunaannya dalam atribut-atribut tradisi seperti warna pakaian adat, ragam hias, umbul-umbul (marawa) atau logo Pemda. Berikut jenis warna dan pemaknaan dalam kebudayaan Minangkabau. Trinanda (2013) menjelaskan bahwa warna Kuning, merupakan lambang dari Luhak Tanahdatar merupakan sektor daerah Minangkabau yang pertama. Disebut juga Luhak Tuo, merupakan daerah pusat pemerintahaan kerajaan Minangkabau (Pagaruyung). Pengunaan payung kuning juga memiliki makna simbolik sebagai perhelatan untuk raja. Warna kuning melambangkan keagungan, punya undang-undang dan hukum dengan kebesaran Luhak Tanahdatar. Falsafah tradisi Luhak 
Tanahdatar (aianyo janiah, ikannyo jinak dan buminyo dingin). Warna kuning digunakan pada pakaian panghulu atau ninik mamak. Dan merupakan warna latar pada logo Pemda Tanahdatar.

Merah, merupakan lambang dari Luhak Agam. Memiliki simbolik keberanian punya raso jo pareso. Luhak Agam disebur juga Luhak Tangah. Luhak agam dikenal sebagai daerah pusat pasukan (pandeka, dubalang) Minangkabau. Pandeka, dubalang menggunakan pakaian tradisi berwarna merah. Falsafah adat Luhak Agam. (airnyo karuah, ikannya lia dan buminya hangat). Pada Logo pemda Agam warna merah menjadi warna latar logo yang memiliki arti semangat yang menyala-nyala, kecintaan pada Negara dan Agama.

Hitam, merupakan warna yang digunakan untuk melambangkan Luhak Limo Puluah Koto. Melambangakan tahan tapo (terpa) serta mempunyai akal dan budi. Luhak Limo Puluah Koto disebut juga luhak Mudo. Luhak 50 Koto ini dikenal sebagai daerah Cadiak Pandai. Falsafah Adatnya (aianyo manih, ikannyo banyak, dan buminyo tawa). Warna hitam digunakan dalam pakaian adat datuak dan cadiak pandai.

Setelah mengetahui simbolik dan psikologi warna, dari tiga unsur warna yang dominan oleh masyarakat Minangkabau, maka warna tersebut di aplikasikan ke dalam bentuk logo 3D puzzle Rumah Gadang Tipe Rajo Babandiang, dengan maksud dan tujuan, bahwa tiga unsur warna ini, kuning, merah dan hitam, sebagai landasan, dan konsep untuk menjadi identitas lokal, bahwa produk 3D puzzle Rumah Gadang Ini, berasal dari Minangkabau

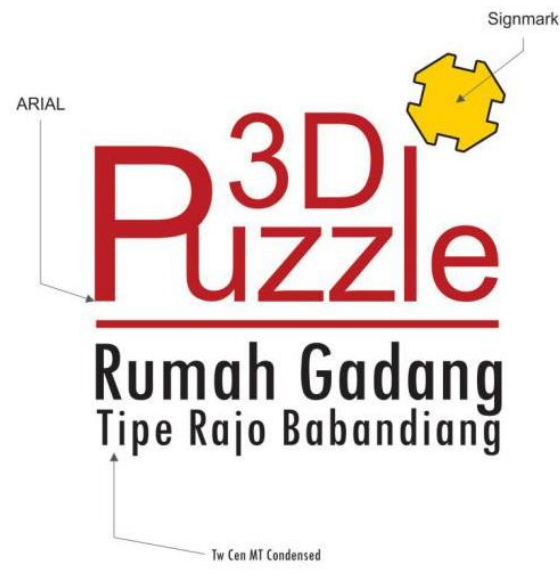

Gambar 38 Mengaplikasikan Warna Logo (Fariko, 2017)

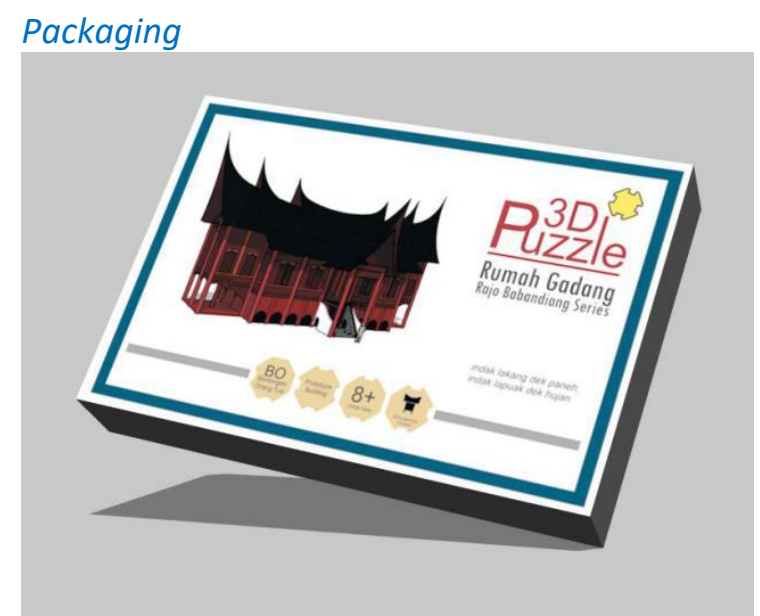

Gambar 39 Tampilan Packaging 3D puzzle Rumah Gadang (Fariko, 2017) 


\section{Simpulan}

Adanya prilaku stereotip masyarakat mengadaptasi penempatan dari ikonik Rumah Gadang yakni bentuk gonjong yang digunakan sebagai bahasa visual untuk atribut suatu bangunan yang semestinya tidak layak dijadikan bergonjong, seperti atap lahan parkir, kandang hewan, plang nama dan sebagainya. Secara kontekstual atap gonjong merepresentasikan sesuatu yang sakral, maka stereotip masyarakat dapat menjadi kegagalan persepsi dikemudian hari.

Konsep rancangan permainan kategori teka-teki berwujud tiga dimensi, yang memiliki kemampuan intelegensi bagi penggunanya. Upaya untuk melestarikan budaya dan nilai-nilai tradisi, terutama pada representasi rumah adat minangkabau. Gagasan karya 3D puzzle Rumah Gadang ini dirancang pada setiap komponen puzzle Rumah Gadang terdiri dari tiang, dinding bilik, atap dan lain-lain, agar dapat mempelajari struktur bangunan, fungsi dan maknanya. Proses merakit elemen puzzle tiga dimensi inilah cara menjawab konsep revitalisasi Rumah Gadang dengan membaca petunjuk kode yang tersedia, selanjutnya menyesuaikannya dengan komponen material puzzle. Karya ini bermanfaat sebagai alat peraga edukatif, membangun pemahaman khalayak sasaran yang bertujuan untuk pendidikan dan kebudayaan generasi muda tidak luntur oleh perobahan zaman.

Karya desain ini berupa prototype, dengan keterbatasan alat, bahan yang didapat, maka perancang dapat mengalami kesulitan dan keterbatasan waktu untuk mencapai hasil yang maksimal. Untuk tahap selanjutnya mendaftarkan hak kekayaan intelektual berfungsi sebagai perlindungan hukum kepada pencipta, juga terhadap hasil cipta karya serta nilai ekonomis yang terkandung di dalamnya. Juga sebagai sebuah perlindungan akan aset berharga yang dipunyai perorangan ataupun kelompok dalam bentuk hasil karya.

\section{Daftar Pustaka}

Amalia, Devi M, Ferina Agustina, and Joko Sulianto. 2017. "Pengembangan Media Diorama Pada Pembelajaran Tematik Terintergrasi Tema Indahnya Negeriku Untuk Meningkatkan Hasil Belajar Siswa." Paedagogia: Jurnal Penelitian Pendidikan 20 (2): 185-198. https://doi.org/https://doi.org/10.20961/paedagogia.v20i2.9850.

Couto, Nasbahry. 2008. Budaya visual seni tradisi Minangkabau. Padang: Universitas Negeri Padang Press.

Departemen Pendidikan dan Kebudayaan. 1990. Ensiklopedi Nasional Indonesia. Jakarta: PT. Cipta Adi Pustaka.

Hasan, Hasmurdi. 2004. Ragam Rumah Adat Minangkabau, Falsafah Pembagunan dan Kegunaan. Jakarta: Yayasan Citra Pendidikan Indonesia.

Hurlock, Elizabeth B. 2005. Perkembangan Anak. Translated by Med Meitasari Tjandrasa. Vol. Jilid 1. Jakarta: Erlangga.

Ibenzani, Usman. 1985. "Seni Ukir Tradisional pada Rumah Adat Minangkabau: Teknik, Pola dan Fungsinya." Doktor Disertasi, Institut Teknologi Bandung.

"The LEGO Group History." Accessed 5 September. https://www.lego.com/en-us/aboutus/legogroup/the-lego-group-history. 
Moleong, Lexy J. 2019. Metode Penelitian Kualitatif. Edisi Revisi ed. Bandung: PT.Remaja Rosdakarya.

Navis, Ali Akabar. 1984. Alam Takambang Jadi Guru. Jakarta: GrafitiPers.

Putiah, Julius DT. Malako Nan. 2007. Membangkik Batang Tarandam dalam Upaya Mewariskan Adat Minangkabau Menghadapi Modernisasi Kehidupan Bangsa. Bandung: Citra Umbara.

Rasmida, Rasmida. 2015. ""Cahayo Garih Tangan Sako Bajawek" Audabe Hoerijah Adam." Doktor Disertasi, Institut Seni Indonesia Surakarta.

Tim Penyusun Kamus Pusat Pembinaan dan Pengembangan Bahasa. 1989. Kamus Besar Bahasa Indonesia. Jakarta: Departemen Pendidikan dan Kebudayaan, Balai Pustaka.

Trinanda, Riri 2013. "Pola Gonjong pada Merek Rumah Makan Padang dalam Perspektif Desain Komunikasi Visual." Magister Thesis, Institut Seni Indonesia Yogyakarta.

Utami, Sri, Nuzul Qur'aniati, and Erlita Kusuma. 2017. "Bermain Lego Meningkatkan Perkembangan Kognitif Anak Usia Pra Sekolah (4-5 Tahun)." Jurnal Ners 3 (2): 121-127. https://e-journal.unair.ac.id/JNERS/article/view/4993.

Winoto, Yunus, Naura Aufa, and Rully Khairul Anwar. 2020. "Model Literasi Informasi Pengajar Dalam Mengembangkan Model Kecerdasan Ruang Visual (Spatial Intelligence): Studi pada para peserta bimbingan belajar Villa Merah Bandung." Pustabiblia: Journal of Library and Information Science 4 (1): $59-78$. https://doi.org/https://doi.org/10.18326/pustabiblia.v4i1.59-78.

Yin, Robert K. 2013. Studi Kasus: Desain dan Metode. Translated by M. Djauzi Mudzakkir. Jakarta: Raja Grafindo. 